Review

\title{
The Realities of Community Based Natural Resource Management and Biodiversity Conservation in Sub-Saharan Africa
}

\section{Paul Andre DeGeorges *," and Brian Kevin Reilly}

Department of Nature Conservation, Tshwane University of Technology, P/Bag X680, Pretoria, South Africa; E-Mail: reillybk@tut.ac.za

\# Retired from Tshwane University of Technology. Current Address: 2201 Mayflower Drive, Greenbackville, Virginia 23356, USA

* Author to whom correspondence should be addressed; E-Mail: andredeg@verizon.net; Tel.:+1-757-854-1303; Fax: +1-703-790-1578.

Received: 15 July 2009 / Accepted: 11 September 2009 / Published: 25 September 2009

\begin{abstract}
This is an historic overview of conservation in Sub-Saharan Africa from pre-colonial times through the present. It demonstrates that Africans practiced conservation that was ignored by the colonial powers. The colonial market economy combined with the human and livestock population explosion of the $21^{\text {st }}$ century are the major factors contributing to the demise of wildlife and critical habitat. Unique insight is provided into the economics of a representative safari company, something that has not been readily available to Community Based Natural Resources Management (CBNRM) practitioners. Modern attempts at sharing benefits from conservation with rural communities will fail due to the low rural resource to population ratio regardless of the model, combined with the uneven distribution of profits from safari hunting that drives most CBNRM programs, unless these ratios are changed. Low household incomes from CBNRM are unlikely to change attitudes of rural dwellers towards Western approaches to conservation. Communities must sustainably manage their natural areas as "green factories" for the multitude of natural resources they contain as a means of maximizing employment and thus household incomes, as well as meeting the often overlooked socio-cultural ties to wildlife and other natural resources, which may be as important as direct material benefits in assuring conservation of wildlife and its habitat. For CBNRM to be successful in the long-term, full devolution of ownership over land and natural resources must take place. In addition, as a means of relieving pressure on the rural resource base, this will require an
\end{abstract}


urbanization process that creates a middleclass, as opposed to the current slums that form the majority of Africa's cities, through industrialization that transforms the unique natural resources of the subcontinent (e.g., strategic minerals, petroleum, wildlife, hardwoods, fisheries, wild medicines, agricultural products, etc.) in Africa.

Keywords: wildlife; conservation; development; CBNRM; population; industrialization

\section{Summary}

Pre-colonial Africa had extensive management systems in place linked to social controls as opposed to purely ecological objectives. European colonizers not only failed to recognize these management systems and their role in maintaining a balance with nature, but with the improved technology of modern firearms along with a capitalist model of exploitation they were the primary cause for the initial demise of wildlife. The approximate 6-fold increase in Sub-Saharan Africa's human populations in the $21^{\text {st }}$ century hastened the decline of both wildlife and critical habitat. Attempts at separating Africans from their natural systems through creation of parks and protected areas that accelerated at the end of the colonial era, often comprising incomplete ecosystems, have and will fall short of conserving biodiversity. They alienate rural Africans, compressing them into areas that fail to sustain them, resulting in soil degradation, poaching of resources and eventual encroachment into these natural protected areas. The dynamic concept of Community Based Natural Resource Management (CBNRM), which developed in Southern Africa in the 1980's as a means of co-opting rural communities into the conservation process by sharing revenue primarily from safari hunting, provides insignificant benefits at the household level, fails to integrate rural Africans and their socio-cultural needs into the management of the protected area, and retains dependency upon a middleman who captures most of the net profits. Governments retain ownership over wildlife and obtain revenue directly from its harvest, being both players and referees. The authors propose African solutions to conservation through development of a multiple-resource use model that increases benefits to individual households and meets their social needs. However, regardless of how it is structured, due to low resource/population ratios in rural Sub-Saharan Africa, CBNRM on its own fails unless it fits into a larger plan for development of urbanization and industrialization through transformation of natural resources in Africa that takes pressure off these rural areas.

\section{Historical Background}

\subsection{Co-Evolution of Man and Wildlife in Sub-Saharan Africa}

The persistence of mega fauna in Africa as opposed to other continents is partly ascribed to co-evolution with proto- and modern humans. The co-evolution of humans and mega-fauna over millions of years provided wildlife "time to learn a healthy fear of man and with it a healthy avoidance of hunters" [1-9]. Unlike other continents, Africa's mega fauna were spared over-exploitation by humans until the relatively recent arrival of the European colonizers about 350 years ago. "Conservation" can be defined as a socio-economic process by which societies endeavour to manage 
resource scarcities and limit off take within the biological capacity of the systems in order to sustain production [10]. While not employing modern Western designed concepts such as measuring carrying capacity, maximum sustained yields, wildlife counting and indices as a means of setting harvest quotas, etc., pre-colonial Africans nonetheless used a number of management interventions. Access to natural resources, including agricultural land, pasture, wildlife, tree products and fish, was controlled by a very strict social hierarchy through extended families and clans, often under the authority of chiefs/headmen/elders [11-15], religious leaders/spirit mediums or hunting guilds [14-21]; borrowed from the ancestors [13] as "Common Property Resources" for the good of the greater community. In addition, taboos/totems [13,14,17,22-24], royal game [11,13,25,26], territoriality [17,19,21,27-35], mobility/migration [30,34,36,37], habitat manipulation (e.g., fire, fallow) [38,39], harvest regulations (e.g., no harvesting of pregnant females or young) and seasons [19,21], resulted in biological and sociological controls over the access to wildlife and other resources. Rules and regulations regarding access to natural resources were precise and codified, although not written down, and had been enforced since time immemorial. The result was sustainable exploitation of natural resources. This had been accomplished with no ecological purpose (e.g., maintenance of biodiversity) in mind, as we understand it, but out of a sheer instinct for self-preservation. Conservation of game animals and fish was necessary in order to provide for survival in the future [40].

\subsection{Colonialism and Post-Colonial Conservation and Its Impact on Traditional Management Systems}

Wildlife became a point of contact between African people's traditional values and European ideas of ownership. European colonists introduced both a strong market economy and firearms that tipped the scales towards over-exploitation [41]. Colonialism expropriated the landscape and alienated Africans from it [42]. Colonialism excluded African beliefs in the intrinsic power and value of nature in favour of Western Judeo-Christian tenets of taming and civilizing nature [41]. As in North America, it suited colonial incomers to overlook signs of native alteration of the landscape; the apparent absence of indigenous improvements, helping to justify the removal of indigenous people from tribal lands to make way for the more sophisticated European settler [40].

For instance, there is strong evidence that the pre-colonial East Africa of the $19^{\text {th }}$ century was not the wildlife paradise that it is today. Many of Tanzania's well-known game reserves and parks of the $20^{\text {th }} / 21^{\text {st }}$ centuries, including the Selous, Ngorongoro Crater, Serengeti, Lake Manyara National Park, and Lake Rukwa Game Reserve, had more people and livestock than wildlife as man dominated both wildlife and habitat through hunting, as well as bush clearing by fire, axe and grazing by livestock [39]. However, by the time the Europeans arrived in East Africa in the 1890s, this life had changed, mainly due to human, livestock and wildlife diseases inadvertently introduced by the colonizers, helping to solidify the latter's prejudices concerning the backwardness of the "natives" and resulted in East Africa's loss of control over nature and the eventual spread of bush. This included rinderpest, smallpox, sand flea, locusts, the Maji Maji Rebellion of 1905 against colonialism ${ }^{\mathrm{i}}$, food procurement for military purposes by Europeans linked to WWI, colonial warfare with the Germans in WWI, forced labour by the Germans/Europeans, famine associated with the above, eventually European imposed wildlife reserves, and eventually villages concentrated as part of tsetse fly control imposed by Europeans. By 1937, 66\% of Tanzania, and thus prime wildlife habitat, was occupied by tsetse fly ${ }^{\text {ii }}$ 
compared to $33 \%$ in 1913 [39]. The combination of these events resulted in the de-development and impoverishment of rural Tanzanians. It is estimated that 750,000 people died of hunger between 1894 and 1899. Also, it is estimated that human populations in the East Africa/Great Lakes region did not return to pre-1890s levels until the 1950s [40]. At a crucial stage in the retreat of man and cattle from the advancement of nature, a new ecological balance was established in which "nature" and "not man" was in control $[39,43]$.

What had been a peaceful relationship between herders and agriculturists, in which trade was implicit and mutually beneficial, broke down, as starving pastoralists began raiding to survive [39]. Kjekshus [39] believes that the intense tribal raiding the Germans experienced upon their arrival in Tanganyika (today's Tanzania) was the direct consequence of economic losses suffered initially through rinderpest. Similar events also occurred in Kenya and Uganda resulting in comparable disruptions in the society and ecology [40]. It is estimated that $95 \%$ of all cattle died in East Africa, resulting in one of the "twin pillars" of the traditional economy - the lifeline of the people — being torn away. Rinderpest was a subduing force aiding the colonial takeover, by taking the fight out of the warlike Maasai. While Maasai morani (warriors) survived through hunting and petty thieving, the majority of the Maasai lived as beggars among neighbouring peasants. While agricultural societies could avoid starvation with their crops, the nomadic pastoralists were starving to death [39].

The European colonizer brought order to perceived anarchy and chaos, disrupting traditional management systems in the process. Western systems of governance were imposed on other cultures, ultimately taking away the self-respect and dignity of once proud people through the creation of second class citizenry subservient to European settlers, a stigma that to this day may still be holding back Africa from the envisioned renaissance [40].

As in North America, wildlife became a resource of European conquest [43], providing income (e.g., ivory and skins) $[43,44]$, and a cheap source of meat for "penetrating the country by feeding the natives" [43]. Wildlife stood in the way of "Civilization and Christianity", competing for space and pasture with livestock, its eradication along with the associated tsetse fly being a prerequisite to European imperialism. Books by mostly English and Scottish explorers, ivory hunters and adventure seekers, many ex-military officers and royalty promoted the myth of a wild, untamed Africa, a savage land, adventure, manliness, nobility and courage. This served as a magnet to draw the hopeless European masses to this land of plenty, where with only a gun and oxcart one could get rich quickly or find wide open spaces on which to settle, a luxury in an over-populated and class-conscious Europe. A similar cry in the 1800s, "Go West Young Man, Go West", encouraged European immigrants to America to seek their fortunes, pushing aside the Amerindians and slaughtering the wildlife (e.g., bison and beaver) for meat and money, with ox-cart and musket/long-rifle in seeking their fortunes. In both cases, some became rich, and many died along the way from resisting indigenes, disease and thirst.

In Southern Africa, this attitude towards wildlife resulted in the asset stripping of game, being worked out like a mineral seam [43]. In 1652, van Riebeeck reported that a French ship in Saldanha Bay had harvested 48,000 seals for their skins and oil over a six month period from around Dassen Island. By 1656, it took the Dutch East India Company three years to harvest 48,000 seals that the French had taken in six months [45]. The Africans, and Boer Afrikaner settlers of Dutch, German and French Huguenot descent, who often collaborated in market-hunting, saw wildlife much differently 
than the "sporting" English gentlemen that were to follow in their footsteps. Boer hunting parties usually consisted of numerous armed zwarteskutters (black marksmen) or jagtkaffers (hunting kaffirs), in an equitable partnership. Wildlife had a utilitarian value for trade and food, which allowed them to assert their independence as they moved into the interior to escape the ever-increasing authority of the British in the Cape [41]. It is estimated in the 1700s that there were 500,000,000 springbok between the southernmost limits of the Karoo and the Kalahari Desert of South Africa and Namibia [46]. One million antelope skins were being exported annually in the 1870s from the Orange Free State [43]. By 1896, these great springbok migrations had nearly come to an end, victims of guns, clubs, advancing civilization, and the cows and sheep that devoured their pasture [46]. In South Africa, the bluebuck (Hippotragus leucophaeus) was extinct by 1800, the Cape warthog, Phacochoerus aethiopicus aethiopicus, by 1860 and the quagga (Equus quagga) by 1870. South Africa had an estimated 100,000 elephants (Loxodonta africana) in the 1650s [46]. In the Old Transvaal, 90,000 kg of ivory was exported in 1855 along with vast quantities of hide and horn [41]. By the turn of the century, the elephant, white rhino, Cape mountain zebra, bontebok and black wildebeest were on the verge of extinction in Southern Africa [40,44] (Table 1).

Table 1. Dates and estimated numbers on the near extinction of key mega-fauna in Southern Africa. Source: [40].

\begin{tabular}{lll}
\hline \multicolumn{1}{c}{ SPECIES } & DATE & ESTIMATE \\
\hline African Elephant (Loxodonta africana) & & \\
& & \\
- South Africa & $1920 \mathrm{~s}$ & 120 \\
- Zimbabwe & 1900 & $<4,000$ \\
- Namibia & 1900 & 300 \\
White Rhino (Ceratotherium simum) & 1895 & 20 \\
Cape Mountain Zebra ( Equus zebra zebra ) & 1922 & 400 \\
Bontebok ( Damaliscus dorcas dorcas) & 1927 & 120 \\
Black Wildebeest ( Connochaetes gnou) & 1890 & 550 \\
\hline
\end{tabular}

The situation in West and East Africa was not much different with these regions being stripped of their wildlife resources (Table 2). It is estimated that between 1608 and 1612, 23,000 kg/year of ivory was imported to Holland alone, mostly from West Africa [47]. In 1909, just one forest concessionaire, the N'Goko-Sangha Company from the Sangha Basin of French Equatorial Africa, exported 6,625 kg of ivory. When another company, CFSO (Compagnie Forestière de la Sangha-Oubangui) took over this concession, its annual exports fluctuated between 2,694 kg in 1911 to 4,105 kg of ivory in 1917 [48]. Between 1937 and 1939, 200,000 elephants were killed in the Belgian Congo (today's Democratic Republic of Congo) for ivory [47]. It is estimated that 2 million duikers were being killed annually for their hides in Francophone Africa south of the Sahara during the 1950s [44].

In Tanzania, from 1903-1911, a total of $256,000 \mathrm{~kg}$ of ivory was exported, representing approximately 1,200 to 1,500 elephants killed/year with the likelihood that significant amounts of ivory were smuggled out on dhows ${ }^{\text {iii }}$ in order to avoid the $15 \%$ export tax of the Kaiser. During this same period (1902-1911), 53,000 kg of rhino horn was exported, representing 2,000 to 2,300 rhino's 
shot/year, while 1,000 live animals, $50,000 \mathrm{~kg}$ of antelope horns and 2,700 $\mathrm{kg}$ of valuable bird feathers were exported to Germany [49]. In Somaliland (Somalia) alone 350,000 dik-dik skins/year (Madoqua sp. and Rhynchotragus sp.) and about 70,000 wildlife skins/year were exported, $80 \%$ of which were giraffe (Giraffa camelopardalis reticulata), gazelles (Gazella spp.) and gerenuk (Litocranius walleri) [50].

Table 2. Confirmed examples of typical wildlife products exported from colonial West and East Africa.

\begin{tabular}{|c|c|c|c|c|c|}
\hline $\begin{array}{l}\text { WILDLIFE } \\
\text { RESOURCE }\end{array}$ & DATE & SOURCE & $\begin{array}{l}\text { QUANTITY } \\
\text { EXPORTED }\end{array}$ & DESTINATION & SOURCE \\
\hline Ivory & $1608-1612$ & Mostly West Africa & $23,000 \mathrm{~kg} / \mathrm{yr}$ & Holland & [47] \\
\hline Ivory & 1909-1917 & $\begin{array}{l}\text { Sangha Basin, French } \\
\text { Equatorial Africa }\end{array}$ & $2,694-6,625 \mathrm{~kg} / \mathrm{yr}$ & France/Europe & [48] \\
\hline Ivory & $1903-1911$ & Tanzania & $\begin{array}{l}28,444 \mathrm{~kg} / \mathrm{yr} \\
\text { representing 1,200-1,500 } \\
\text { elephants/yr }\end{array}$ & Germany/Europe & [49] \\
\hline Rhino Horn & 1903-1911 & Tanzania & $\begin{array}{l}5,889 \mathrm{~kg} / \mathrm{yr} \\
\text { representing 2,000-2,300 } \\
\text { rhino/yr }\end{array}$ & Germany/Europe & [49] \\
\hline Duiker Skins & 1950 & $\begin{array}{l}\text { Sub-Saharan } \\
\text { Francophone Africa }\end{array}$ & 2 million/yr & France/Europe & [44] \\
\hline $\begin{array}{l}\text { Dik-dik Skins } \\
\text { (Madoqua sp. \& } \\
\text { Rhynchotragus sp.) }\end{array}$ & $\begin{array}{l}\text { Mid- } 20^{\text {th }} \\
\text { Century }\end{array}$ & Somaliland & $350,000 / \mathrm{yr}$ & Europe & [50] \\
\hline
\end{tabular}

\subsection{The Coming of Game Laws, Parks and Reserves}

The perception of the colonial masters was that Africans and their poaching activities were the reason for declining wildlife numbers [41,43,51]. Even though Africans had co-evolved with wildlife, the colonial powers failed to recognize that it was the coming of the European, with superior technology, the "modern firearm," and the commercialization of wildlife in a way that Africa had never seen (Figure 1), along with the westerners desire to have dominion over nature (e.g., fencing the land, conversion of natural systems into cultivated land and competition with livestock for pasture) that brought a number of species to extinction or near extinction. This was eventually compounded by the human and corresponding livestock population explosions on the subcontinent in the $20^{\text {th }}$ century. Human populations exploded during the $20^{\text {th }}$ century because of improved parasite control and medical care. This placed much of rural Sub-Saharan Africa out of balance with nature on marginal savannah soils that compose $70-75 \%$ of the subcontinent, and associated resources (e.g., wildlife) [40]. 
Figure 1. Introduction of modern firearms and commercialization of wildlife helped bring a number of wildlife species to near extinction. Source: Principal author, Turkana, northern Kenya, with traditional long bow and British Enfield, 1992.

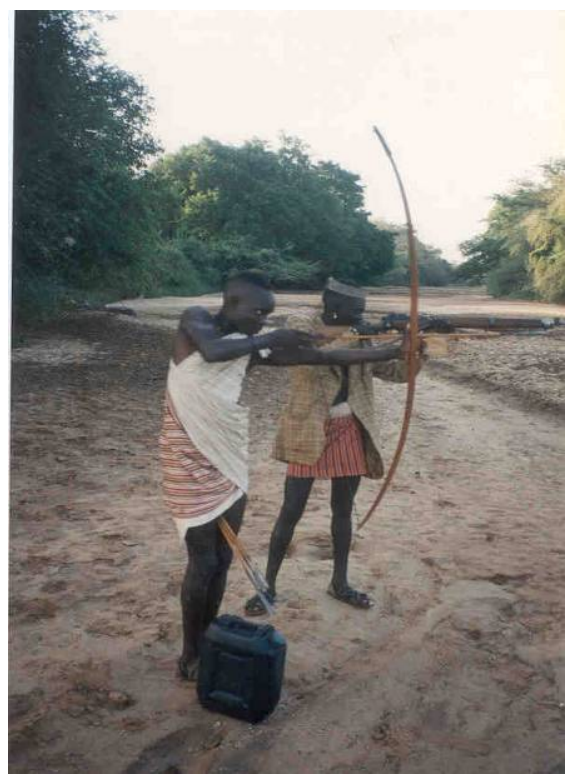

Once the scramble for Africa was over and the continent had been carved up, it belonged to everyone but native Africans. The culture of hunting in Europe was turned into part of the culture of European Imperialism in Africa [41]. European imperialism also excluded Africans and their traditional hunting methods as "un-sporting," and "not fair chase", failing to recognize that Africans had always conserved wildlife and habitat as part of their cultural heritage and survival network. The Game Law Amendment of 1891 and the Game Preservation Ordinance Act of 1899 brought about the end of frontier exploitation by adventurers like ivory hunters in Southern Africa. Though passed in the Cape of Good Hope (a British colony), the game legislation was imposed on the British South African Company (BSAC) in its charter by the imperial state. Thus the game laws would be applied to the (BSACs) territory, later (in 1923) to become Northern Rhodesia, Southern Rhodesia and Nyasaland (modern day Zambia, Zimbabwe and Malawi, respectively) [15,52-57]. The colonial masters of England, France, Belgium, Portugal and Spain signed the first international conservation treaty in 1900, "The Convention for the Preservation of Animals, Birds and Fish in Africa". The goal of this treaty was to save African wildlife for hunting by royalty and upper class Europeans, and for ivory [58]. Africans had their traditional governance and resource management systems usurped by Western laws [15,52-57]. In 1933, an International Conference for the Protection of Flora and Fauna of Africa, held in London, laid down the principles on which national parks were to be established. Human populations were moved off of and denied access to their traditional hunting grounds, burial sites, sacred forests, etc. Traditional hunters and resource exploiters were turned into poachers (Figure 2) and alienated from these imposed management systems. Policies such as regroupement that concentrated Africans along major roads where they could be more easily administered [27,48] resulted in modified forest and savannah ecology, and soil degradation from decreased fallow. Exclusion from accessing parks and protected areas saw bush encroachment and declining biodiversity in many savannah areas, a failing by Western conservationists to understand the anthropogenic role 
man played in the evolution of African savannah and forest ecology [40]. Parks and game reserves were "white inventions, which elevated wildlife above humanity, which served as instruments of dispossession and subjugation" in which Africans were non-partners who were neither able to continue their traditional subsistence lifestyles in conserved areas, nor were fully co-opted into the system of Western conservation imposed on them [41,59].

Figure 2. Creation of parks and protected areas turned traditional hunters into poachers. Source: Principal author, Baka Pygmies, southeastern Cameroon, 2001.

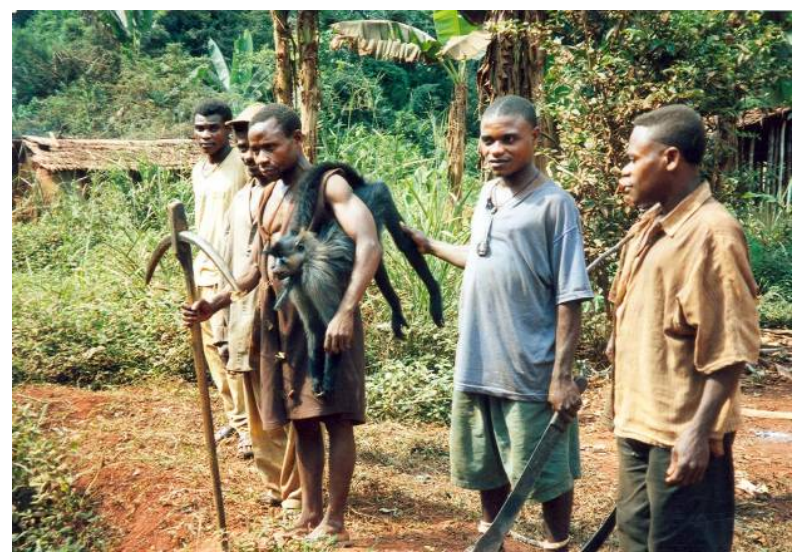

At the same time in Southern Africa and to a lesser degree in East Africa (especially Kenya), indigenous people were forced off their land to make way for European settlers. A major issue facing land reform in Southern Africa is the significant difference in how black and white Africans relate to the land. Traditionally for the black African land belonged/s to the ancestors and through the lineage group was allocated by the village head/chief to a head of household. It was returned to the lineage group for redistribution when the household stopped farming the plot of land and/or the head of the household died. No individual could own a piece of land. For the white settler/African, based upon his/her European ancestry, land was/is owned with a title deed, demarcated and fenced by an individual; a commodity which could be bought and sold. The black African related to land as something sacred tied to his/her ancestors, whereas the white African related to the landscape - nature, the wildlife and the products that he/she could obtain from the land, but which the black African felt must be returned to his/her ancestors [47]. The liberation war of Zimbabwe or "Chimurenga" was fought over rectifying the brutal injustices with regards to land and the liberation fighters were known as Vana Vevhu or "children of the soil". One could argue that this "war" is still being played out at the beginning of the $21^{\text {st }}$ century, especially in Kenya, Zimbabwe, Namibia and South Africa [40].

\subsection{Parks and Protected Areas in the $20^{\text {th }} \& 21^{\text {st }}$ Century}

In 1990, the World Parks Commission set a goal of protecting 10\% of the planet's surface. In Sub-Saharan Africa, over a million $\mathrm{km}^{2}$ of land has been set aside as national parks and game reserves, yet they have been remarkably unsuccessful at protecting wildlife [60]. This can only happen at the expense of displacing and compressing rural Africans into smaller and smaller areas, along with increased impoverishment and habitat degradation in the compressed areas [60]. The International Union for the Conservation of Nature's (IUCN) ${ }^{\text {iv }}$ classification of protected areas covers 6 categories 
ranging from extreme protection (Categories Ia-III) with Category II a national park, to conservation/management interventions in (Categories IV-VI) with Category VI allowing a "sustainable flow of natural products and services to meet community needs [61]. Unfortunately in Africa, there are few protected areas under Category VI. In Africa alone, it is estimated that there have been from 14 million [62] to as many as 39.5 million internally displaced persons (IDPs) from creation of parks and protected areas, the latter figure extrapolated by using 1997 IUCN protected area data and 25 persons $/ \mathrm{km}^{2}$ [63]. The majority of this displacement has occurred within the last 30 years (1970-2000) [63] and continues.

Much of this has taken place as a result of collusion between Western NGOs (non-governmental organizations), Western donors and African governments. For instance, Conservation International (CI), The Nature Conservancy (TNC), the World Wildlife Fund (WWF), and the Wildlife Conservation Society (WCS) among the five largest conservation organizations (or BINGOS/Big conservation NGOs) absorbed over $70 \%$ of the US\$ 300 million put into international conservation by USAID (United States Agency for International Development) in the 1990s [62].

Given today's level of poverty and human population growth, one of the actions that may be necessary in the $21^{\text {st }}$ century is the reclassification of most protected areas to Category VI, since protected areas classified under other categories are being rapidly encroached upon and/or poached out by alienated communities opting out for other land uses as a survival mechanism. Many African countries appear to have gone overboard in achieving this 10\% goal (Figure 3) [64].

Figure 3. Percentage protected area of total territorial area (terrestrial and marine) of representative Sub-Saharan countries, 2008. Source: [64].

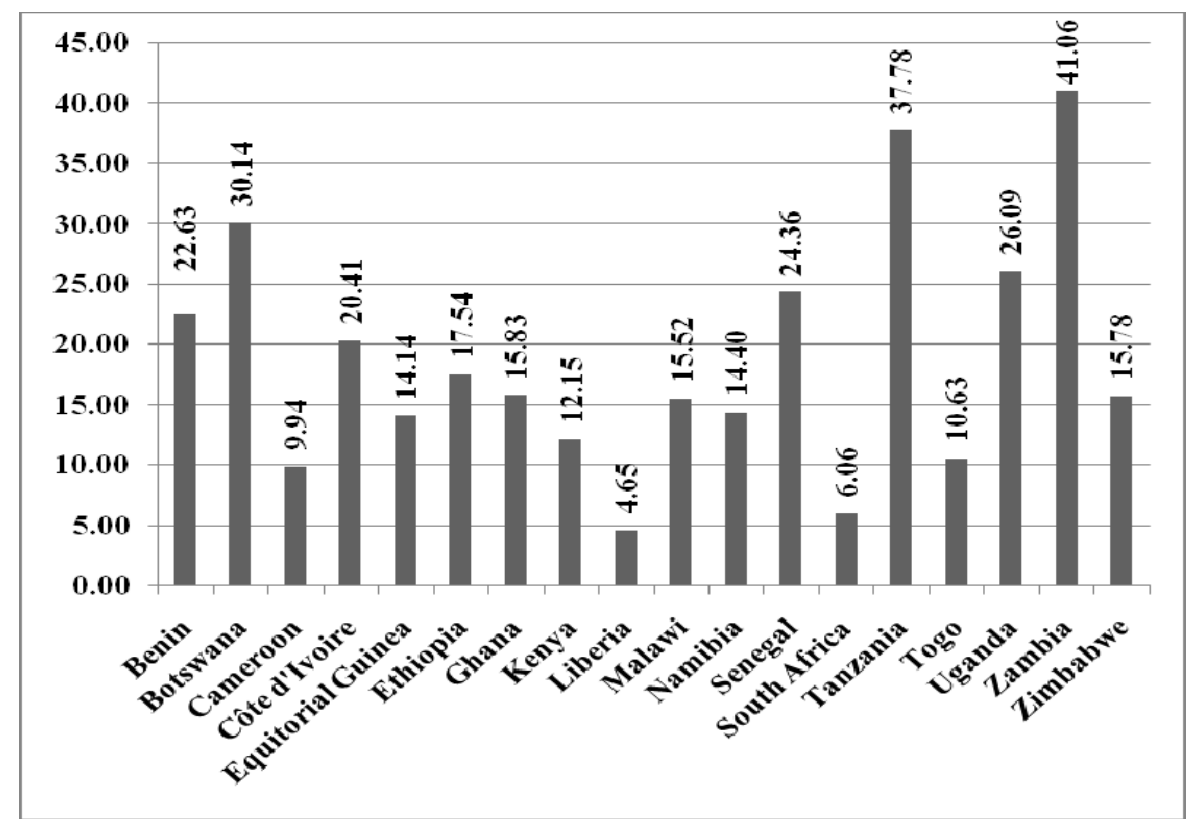

Kjekshus [39] provides an excellent historical overview for the removal of indigenous people in East Africa beginning in the 1890s and accelerating near independence, including:

- The forced removal of 500 people from the Gombe Stream Chimpanzee Sanctuary, just north of Kigoma on the shores of Lake Tanganyika. 
- The Mbulu Game Reserve, Tanganyika, containing 10,000 people, their settlements and 1,000s of acres of grazing land.

- The Katawi and Sabi River Game Reserves, Tanganyika where the removal of people was required.

- The Serengeti Game Reserve, in which the Maasai lost $83 \%$ of their former land area.

- The Selous Game Reserve (SGR) from which 40,000 people were moved.

- The Budonga Game Reserve by Lake Albert, Uganda, from which people were eventually removed to protect them from tsetse fly and to encourage the proliferation of wildlife over the $12,950 \mathrm{~km}^{2}\left(5,000 \mathrm{mi}^{2}\right)$ reserve [43].

Eventually, the Maasai would be pushed off more land including Ngorongoro Crater in the 1950s. Between the late 1940s and 1970, seven protected areas were created in Maasai areas, further restricting the Maasai people's range: Nairobi, Amboseli, Tsavo National Parks and the Maasai Mara in Kenya, and Serengeti, Tarangire and Lake Manyara National Parks in Tanzania. Many of these parks/reserves have been managed as isolated islands of game protected from people like the Maasai. The compression of Maasai into smaller and smaller areas bordering these parks has resulted in overgrazing and habitat degradation. However, this wildlife is not contained entirely within these reserves. In fact, it is believed that in Kenya, $80 \%$ of the wildlife is found or dependent on $80 \%$ of the critical wildlife habitat outside parks and reserves. The areas outside the parks/reserves serve as rainy season dispersal areas where young are born, as well as giving habitat within these protected areas an opportunity to recover from grazing/browsing [40]. Carruthers [41] provides an excellent history of Kruger National Park, South Africa and the eventual forced removal of its residents on a large scale by the 1950 s [40].

In the early 1990s, Ogwang and DeGeorges [69] documented the use of USAID money in collaboration with Uganda's national parks service (today's Uganda Wildlife Authority/UWA) and various NGOs to evict and/or prevent residents from accessing critical natural resources necessary for their livelihood to create Bwindi, "The Impenetrable Forest" (first WWF and then WCS) to protect 300 IUCN "Critically Endangered" mountain gorillas (Gorilla gorilla beringei), and Lake Mburo National Parks, as well as attempts to move people out of the Rwenzori National Park (WCS). Hulme [70] provides a more up-to-date analysis on Lake Mburo where as many as 80,000 cattle are estimated to graze during the dry season, many of them illegal. Colchester [60] gives a number of examples, citing that of the Kibale Game Corridor, linking Kibale Forest to Queen Elizabeth National Park, Uganda, where 30,000 people were removed against their will. In many instances, these parks have enclave communities such as fishermen in Lake Mburo and Queen Elizabeth National Parks and/or allow access to some resources such as minor forest products, but not economically important timber as in Bwindi. There is some revenue sharing with communities, though minor at the household level [40].

This disenfranchisement continues into the $21^{\text {st }}$ century. In many parts of Africa, including Botswana, South Africa, Tanzania and Gabon, the majority, by area, of strictly protected areas have evictions reported [65-67].

Igoe and Croucher [68] demonstrate how communities around Tarangire National Park (TNP) have been coerced by African Wildlife Foundation (AWF), "officially designated by the Tanzanian government to oversee the establishment of WMAs in northeastern Tanzania" and the Wildlife 
Division into forming Burunge WMA, located on the northwestern side of the park. This has resulted in the eviction of people from the WMA, and mainly brought benefits to safari operators, the Wildlife Division and a few village elites, while meeting the agenda of AWF for fundraising and to form wildlife corridors connecting the major parks of Maasailand.

Magome, Grossman, Fakir and Stowell [71] provide an excellent historical perspective on how the 47,000 ha Madikwe Park, South Africa went from white-owned to black-owned cattle ranches and then into a park. Lack of land tenure rights by the Madikwe community is a major weakness in their being able to bargain for an appropriate share of the benefits from this venture. In fact, the state has taken ownership.

The Central Kalahari has been occupied for hundreds of thousands of years by hunters and gatherers (e.g., G/ui, G//ana, and some Kua San), and since the early part of the first millennium AD by agro-pastoral populations (e.g., Bakgalagadi). The Central Kalahari Game Reserve (CKGR) was established in 1961, prior to independence (1966) to protect resident human populations (including San and Bakgalagadi), wildlife and the unique ecological landscape. Hitchcock [29] goes into some detail over the forced removal of San (Basarwa) from the CKGR in 1997, 2001 and 2002 to the resettlement villages of New! Xade and Caudate. Attempts in 2002 to take the matter of residential rights in the CKGR to court were dismissed on a technicality. The case was successfully appealed [72] and in a landmark decision, Botswana's High Court ruled on December 13, 2006 that the so-called Bushmen of the Kalahari were illegally evicted from their ancestral land and should be allowed to return. However, according to Survival International [73], the government has done everything it can to make their return impossible. It has:

- Banned them from using their water boreholes,

- Refused to issue a single permit to hunt on their land,

- Arrested more than 50 Bushmen for hunting to feed their families,

- Banned them from taking their small herds of goats back to the reserve.

Its policy is to intimidate and frighten the Bushmen into staying in resettlement camps, and making the life impossible for those who have gone back to their ancestral land.

Over the last 10 years, the Baka Pygmies and others of south-eastern Cameroon have lost legal access to $70 \%$ of their forests through the creation of parks and hunting blocks with Western funding from the Global Environment Facility (GEF) managed jointly by the World Bank, UNDP (United Nations Development Program) and UNEP (United Nations Environmental Program) and paid for by industrialized countries channelled through Western NGOs and sanctioned by the Cameroonian government. These same processes continue across the borders in Congo Brazzaville and the Central African Republic linked through the transnational Lobeké/Dzanga-Sangha/Nouabalé-Ndoki "TriNational De La Sangha" National Park [40].

Sadly, to date, few if any human rights NGO's have held the conservation NGO's, Western donors or African governments/leaders accountable for what they are doing to indigenous peoples in the name of conservation; resulting in environmental degradation, impoverishment, malnourishment and cultural genocide. It would seem that words like "biodiversity", "conservation" and "endemism", are part of some holy grail that is there for the good of mankind and not to be questioned. These groups appear 
accountable to no one in terms of consequences to people. The Cameroon goal is to have $30 \%$ of its territory in protected areas under pressure from the World Bank [40]. South Africa, with 6.06\% of its land in protected areas in 2008, would have to designate about $50,935 \mathrm{~km}^{2}$ (an area slightly smaller than the total territorial area [terrestrial and marine] of Holland, 1.6 times that of Belgium and 12\% of France) to attain its $10 \%$ goal of land under conservation. However, if one adds in the 1999 estimate of 17 million ha in private game ranches [40], though not considered part of the formal protected area network, they are 2.2 times South Africa's protected area network and over 3 times the amount of land needed to achieve $10 \%$.

The Western world seems to have forgotten that there were people using these natural areas before they were declared parks, game and forest reserves. By compressing people onto land that can no longer support them (e.g., similar to homelands in South Africa, communal lands in Zimbabwe and tribal lands in Kenya), the Western conservation world is forcing rural Africans 1) to degrade their environment, 2) opt for other land uses (e.g., agriculture and livestock), 3) poach as a means of survival and protest $[41,74]$ and 4) flock to the cities in search of a better life, which usually is nonexistent. For many, this is resulting in "politics of despair,", returning to the rural areas to illegally access and eventually mine what have become "open access"vi resources in protected areas which are no longer being managed, but defended against people who have been alienated from Western philosophies of conservation. This is resulting in the loss of habitat and biodiversity [40]. Is this any different from what happened during the colonial era to the Indians in North America or Sub-Saharan Africa where indigenous people were displaced, to make way for European farmers, onto reservations, homelands or communal areas that could neither ecologically nor economically support them? Only today, people are being displaced in the name of the elephant, gorilla and "biodiversity", with the same dire economic and social consequences, and impoverishment; agendas pushed by Western NGOs and supported by their donors and African political elite. This is what might be called "Global Apartheid" in which large tracts of Sub-Saharan Africa are being set aside for a "Global Elite," consisting of transnational eco-tourists, safari hunters, the private companies who serve these clients, governments, Western NGOs and their researchers. Is this sustainable?

\section{CBNRM, an Attempt to Mitigate the Past}

\subsection{Community Based Natural Resource Management (CBNRM)}

Community Based Natural Resource Management (CBNRM) is a concept made popular in the mid-to-late 1970s beginning with Zimbabwe's development of the Communal Areas Management Program for Indigenous Resources (CAMPFIRE), with significant review in the literature [74-83]. It was eventually funded by USAID. Because of its perceived success and for political reasons [40], similar programs developed in other East and Southern African countries that have also been extensively reviewed in the literature, much of this information being readily available online for those readers wishing to delve deeper into a particular country's CBNRM program: 
- ADMADE-Zambia, "Administrative Management Design for Game Management Areas" funded by USAID through the Wildlife Conservation Society (WCS) of the New York Zoological Society [84-94];

- NRMP-Botswana, "Natural Resources Management Program", also called Botswana Community Trust Program funded by USAID through a U.S. consulting firm, CHEMONICS [95-97]

- LIFE-Namibia, "Living in a Finite Environment" run through World Wildife Fund (WWF)/USA and funded by USAID [97-104];

- SCP-Tanzania, "Selous Conservation Program (SCP)" funded by the German funding agencyGTZ [105-113];

- LIRDP-Zambia, "Luangwa Integrated Resource Development Project" funded by the Norwegian Agency for International Development (NORAD) [113,114]

Traditionally, CBNRM was initiated in areas outside the park estate, co-habited by humans and wildlife bordering parks or in game reserves that were designated as hunting blocks [115]. CBNRM appears in many guises, including Integrated Conservation and Development (ICD), CommunityBased Conservation (CBC), Community-Based Natural Resource Management (CBNRM), Community Wildlife Management (CWM), Collaborative (or Co-) Management (CM) and Protected Area Outreach Projects [116].

Since administration and control through repression by centralized governments was not saving wildlife, the idea arose of sharing wealth from the sustainable use of resources with rural people. Donors recognized that African states were unable to centrally manage natural resources and with the re-emergence of democratic aspirations, Western donors began pushing for the devolution of resource rights to peripheral communities living in and around the parks and protected areas. Donors brought along their own baggage including decentralization, gender, transparency, democratization [89] and often compliance with IMF/World Bank structural adjustment policies (SAPs) ${ }^{\mathrm{vii}}$ as a prerequisite for donor support. Thus, while the stimulus, staffing and concepts did not come from the rural communities, nor were the resources expended directly on these communities, they were expected to receive Western donor/NGO driven projects gratefully as passive recipients to participate in proscribed "communities, and to accept benefits in prescribed packages" [92] that often failed to fit within the socio-cultural traditions of these rural small-scale societies. The idea was that community conservation would fulfil human needs, with conservation being the means to achieving and maintaining this end [117]. These donor driven CBNRM programs tend to reward rural Africans for the loss of access to their resources, primarily in hunting blocks, by providing them with material compensation for foregoing traditional ties to wildlife and other resources; "communities do not have the right to use wildlife, only the right to benefit from the use of wildlife by others" [118] with no attempt at identifying ways by which communities manage communal resources (e.g., grazing, wildlife, fisheries, etc.). As a result, most local people still see wildlife as belonging to national government and/or local government, depending on the program [118]. 


\subsection{Economics of CBNRM, a Major Shortcoming}

Many individuals and groups (e.g., international sport hunting fraternity, Western donors) support the concept of sharing revenue from hunting with rural communities as a catalyst for development and as a means of co-opting communities into modern conservation, but have little insight into the realities on the ground, especially the economics of CBNRM. Unfortunately, while the total monetary sums may appear significant, at the household level other than in Botswana-if the money ever gets there (most often used for common property benefits) — the amount is insignificant (Table 3) due to: 1) the majority of the value added from wildlife, primarily from overseas trophy hunting is captured by governments (trophy, license and area fees), and mostly expatriate and/or white and black African (usually politically connected) safari operators not originating from the communal areas, and 2) the resource to human population ratio is too low. Fabricius; et al. [119] found that where resources have high unit value, such as mega-fauna, once the beneficiaries are relatively small (less than 100 households) or at densities less than 20 people $/ \mathrm{km}^{2}$ [79,120], the income/household from communitybased wildlife management can be relatively high. Based upon the information in Table 3, few if any current communities within existing CBNRM programs meet these criteria. In fact, nowhere in CAMPFIRE has wildlife come to represent a viable mechanism for household accumulation, though it is seen as beneficial to the extent that it subsidizes local authorities (Rural District Councils/RDCs) [118].

As noted, the distribution of profits from safari hunting also plays an important role in low household income levels. One of the most difficult problems in CBNRM is obtaining accurate figures from any private sector safari operator on the cost of doing business, net profits and distribution of these profits; as it is not in their interest. During the period (1995-2001) the principal author managed the Africa office for the sport hunting organization Safari Club International (SCI), representing about 30-40,000 overseas trophy hunters (the buyers), professional hunters and safari operators (the sellers). SCI technical staff tried in vain to obtain information from safari operators on cash flow in the safari industry. The information in Table 4 is gleaned from a 2002 proposal to the Uganda Wildlife Authority (UWA) put together by the principal author, after leaving SCI, in collaboration with Franz Wengert, one of the most successful operators in the history of safari hunting in Tanzania. It is based upon his Tanzanian safari operation's costs (government fees, professional hunter salaries/costs, dipping and packing, local staff salaries, marketing, running costs) and Tanzanian government fees (e.g., trophy fees, gun licenses, client hunting licenses, hunting block fees, work permits, company license, dipping and packing) and the business model of the very successful Tanzanian-based Wengert Windrose Safaris that he had just sold. Thus, the information contained in Table 4 is believed to be typical of a safari company in East and Southern Africa. 
Table 3. Value (US\$) of safari industries and economic benefits from related CBNRM programs by country.

\begin{tabular}{|c|c|c|c|c|}
\hline Country & Annual Value (US\$) & $\begin{array}{l}\text { Employment } \\
\text { (1999) }\end{array}$ & $\begin{array}{c}\text { Annual } \\
\text { Community } \\
\text { Benefits (US\$) } \\
\end{array}$ & $\begin{array}{c}\text { Annual Community Benefits Per } \\
\text { Household (US\$) }\end{array}$ \\
\hline Botswana & $\begin{array}{l}\text { Gross US\$ } 12.5-20 \\
\text { million from trophy } \\
\text { hunting, }\end{array}$ & $>1,000$ & $\begin{array}{l}1,696,272.00 \\
\text { gross in } 1999 \\
8.5 \%-13.6 \% \text { of } \\
\text { gross turnover }\end{array}$ & $\begin{array}{l}\text { Sankuyu Community: Ngamiland } \\
\text { (ND) Area 34, 1996-2001: 22-50 } \\
\text { households: US\$ 1,190-9,577 gross } \\
\text { Khwai, Ngamiland Area 18, } \\
\text { 2000-2002: } 35-50 \text { households: US\$ } \\
\text { 4,536-6,480 gross } \\
\text { Okavango Community Trust: ND } \\
\text { 22 \& 23, 2000-2004: } 300-500 \\
\text { households: US\$ } 800-1,333 \text { gross }\end{array}$ \\
\hline Namibia & $\begin{array}{l}>\text { US\$ } 42 \text { million gross } \\
\text { from trophy \& biltong } \\
\text { hunting, venison and live } \\
\text { sales in } 1999\end{array}$ & $\begin{array}{l}2,125 \text { directly } \\
\text { employed in } \\
\text { hunting } \\
\text { industry }\end{array}$ & $\begin{array}{l}\text { Mostly on private } \\
\text { farms but } \\
\text { increasingly on } \\
\text { communal } \\
\text { conservancies: }\end{array}$ & $\begin{array}{l}\text { Nyae Nyae Conservancy, 1997- } \\
\text { 2002: } 400 \text { households: US\$ } 79 \\
\text { gross } 1998 \text { to 2002, } 196 \text { gross in } \\
2003 \\
\text { Torra Conservancy, 2002: } 120\end{array}$ \\
\hline & $\begin{array}{l}>\text { US } \$ 4.7-5 \text { million } \\
\text { gross from trophy } \\
\text { hunting }(11 \%-12 \% \text { of } \\
\text { gross }) \text { in } 1999\end{array}$ & $\begin{array}{l}900 \text { directly } \\
\text { employed in } \\
\text { allied } \\
\text { industries }\end{array}$ & $\begin{array}{l}\text { Nyae Nyae: } \\
\text { average US\$ } \\
48,415 / \text { year gross }\end{array}$ & $\begin{array}{l}\text { households, US\$ } 853 \text { gross }{ }^{\text {viii }} \text {, US\$ } \\
363 \text { net for household \& community } \\
\text { projects: Trophy hunting + Lodge }\end{array}$ \\
\hline South Africa & $\begin{array}{l}\text { Gross of US\$ } 38,395-39 \\
\text { million from overseas } \\
\text { trophy hunting in } 1999 . \\
\text { US\$ } 140-464 \text { million } \\
\text { gross from tourist } \\
\text { hunting, taxidermy, live } \\
\text { sales, biltong hunting \& } \\
\text { venison market }\end{array}$ & $\begin{array}{l}5,000-6,000 \\
\text { jobs from } \\
\text { foreign } \\
\text { hunting } \\
63,000 \text { jobs } \\
\text { On Game } \\
\text { Farms }\end{array}$ & $\begin{array}{l}\text { Negligible, } 99 \% \\
\text { hunting on private } \\
\text { white owned } \\
\text { farms }\end{array}$ & \\
\hline Tanzania & $\begin{array}{l}\text { Grosses of from US\$ } \\
27-39 \text { million/year }\end{array}$ & & & $\begin{array}{l}\text { Selous Conservation Program, } \\
\text { 1990s to present: } 16,500 \\
\text { households: US\$ } 20.60 \text { Gross, US\$ } \\
\text { 15.84-16.13 Actual to community } \\
\text { Cullman-Hurt Community } \\
\text { Wildlife Project, 1990s: US\$ } \\
\text { 14.50-120 Gross }\end{array}$ \\
\hline Zimbabwe & $\begin{array}{l}\text { Gross US\$ } 18.6-22.3 \\
\text { million, pre- } 2000 \text { (land } \\
\text { reform significantly } \\
\text { reduced this income after } \\
2000 \text { ) }\end{array}$ & - & $\begin{array}{l}\approx \text { US } \$ 1.56 \\
\text { million gross. } \\
90 \% \text { from } \\
\text { hunting, } 60 \% \\
\text { from elephant } \\
\text { hunting } \\
7-8.4 \% \text { of Gross } \\
\text { Turnover }\end{array}$ & $\begin{array}{l}\text { CAMPFIRE, Average 1989-1999: } \\
\approx 95,000 \text { households: US\$ } 18.60 \\
\text { gross }\end{array}$ \\
\hline Zambia & $\begin{array}{l}\text { Gross US\$ } 12 \text { million in } \\
1999\end{array}$ & $\begin{array}{l}21 \text { hunting } \\
\text { companies } \\
\text { employing } \\
400 \text { people }\end{array}$ & $\begin{array}{l}\text { US } \$ 700,000 \\
\text { gross, Gross } \\
5.8 \% \text { of Gross } \\
\text { Turnover }\end{array}$ & $\begin{array}{l}\text { ADMADE Program, 1991: } 1,000 \\
\text { households Munyamadzi Corridor } \\
\text { only, US\$ } 17 \text { gross } \\
\text { LIRDP, 1990s: } 10,000 \text { Households, } \\
\text { US\$ 22-37 Gross }\end{array}$ \\
\hline
\end{tabular}


Table 4. Annual income distribution from overseas sport hunting with outside safari company in a Ugandan management hunting block in 2002.

\begin{tabular}{|c|c|c|}
\hline COSTS AND BENEFITS & US\$ & $\begin{array}{l}\text { \% OF NET PROFITS } \\
\text { (gross turnover) }\end{array}$ \\
\hline GROSS TURNOVER & 818,402 & \\
\hline Government Portion of Trophy Fee & 138,000 & \\
\hline Gun Licenses & 6,000 & \\
\hline Dipping Packing and Export Fees & 8,500 & \\
\hline Client Hunting Licenses & 22,750 & \\
\hline Hunting Block Fees (4 Blocks) & 20,000 & \\
\hline Professional Hunters Licenses (5) & 10,000 & \\
\hline Work Permits (5) & 2,500 & \\
\hline Company License & 2,000 & \\
\hline NET INCOME TO GOVERNMENT (UWA) & 209,750 & $\begin{array}{l}39(25.6 \% \text { of gross } \\
\text { turnover) }\end{array}$ \\
\hline Remaining to Company & 608,652 & \\
\hline \multicolumn{3}{|l|}{ RECURRING COSTS } \\
\hline PH DAILY RATE US\$ 150/HUNTING DAY, 360 DAYS & 54,000 & \\
\hline CAR RATE TO PH US\$ 70/HUNTING DAY, 300 DAYS & 21,000 & \\
\hline PH TRAVEL DAY US\$ 40/TRAVEL DAY & 2,800 & \\
\hline SALARY 2 NON HUNT PROF, US\$ 100/DAY & 40,824 & \\
\hline Salary CEO & 20,000 & \\
\hline COMPANY RUNNING COSTS (ELEC, FUEL) & 100,000 & \\
\hline MARKETING & 20,000 & \\
\hline Dipping Packing Fees & 14,500 & \\
\hline Subtotal & 273,124 & \\
\hline Net To Company & 335,528 & \\
\hline \multicolumn{3}{|l|}{ COMMUNITY BENEFITS } \\
\hline GENERAL STAFF & 15,000 & \\
\hline OFF SEASON ANTI-POACHING (4 MOS) & 15,000 & \\
\hline $20 \%$ Of Total Trophy Fee (Govt. + Company) & 47,942 & \\
\hline NET INCOME TO COMMUNITY & 77,942 & $\begin{array}{l}14 \text { (9.5\% of gross } \\
\text { turnover, } 5.9 \% \text { if } \\
\text { salaries discounted) }\end{array}$ \\
\hline NET PROFIT TO COMPANY & 257,586 & $\begin{array}{l}47 \text { (gross profit } \\
\text { margin } 32 \% \text { ) }\end{array}$ \\
\hline TOTAL NET PROFIT & 545,278 & \\
\hline
\end{tabular}

Compiled in collaboration with Franz Wengert, former owner of Wengert Windrose Safaris, Tanzania, in registering Uganda Windrose Safaris using Tanzania costs and business model of Wengert Windrose Safaris. Source: [40]

It is estimated that the percentage of net profits for a typical safari company after recurring costs are factored out at 47\%, 39\% to the government-making government both player and referee, and $14 \%$ for the communities, with a gross profit margin ${ }^{\mathrm{ix}}$ to the safari company of $32 \%(65 \%$ of gross turnover if operational costs included) (Table 4) [40]. This is slightly higher than the 20-25\% safari company's gross profit margin suggested by Hurt and Ravn [121]. De la Harpe, et al. [122] provide a rule of thumb recommendation for communities/landholders to negotiate $33 \%$ of the gross turnover from hunting and $10 \%$ of the turnover from tourism. DeGeorges and Reilly [40] estimated that in the above scheme the community would receive only $9.5 \%$ of the gross turnover from hunting (Table 4). Similarly, it is estimated that CBNRM communities in Southern Africa capture only $5.8-13 \%$ of the gross turnover from safari hunting (Table 3 and Figure 4). Thus, in most cases, governments and private sector have become indispensable middlemen between the people and their resources. By the 
time money filters through all the interest groups (national and local government, private sector, NGOs), whether its origins come directly from the resource base or indirectly from a donor, little or nothing reaches the people. However, there may be individual communities that do not show up in national analyses as presented in Table 3. Regardless, due to the low resource to household ratios, as currently practiced with the exception of Botswana, it is likely that few if any communities would significantly benefit at the household level even if the cash flow to communities from CBNRM could be increased 10-fold, something that is unrealistic.

Though controversial, one has to ask if analysts such as Patel [123] are not too far off in concluding that many of the CBNRM and hunting programs keep rural communities marginalized while maintaining the old colonial ties between the safari operators and governments. As late as August 2005 in the new South Africa, rural black communities in a presentation to the Ministry of Environment and Tourism had the following to say concerning the safari industry,

“...this industry is an 'old boys club' of white men who keep the clients and their networks to themselves for financial gain. The standards and requirements set for one to become a professional hunter, which you need before being registered as an outfitter, or before you can become the director of a hunting academy, are stacked against black individuals" [124].

Figure 4. Annual gross income from safari hunting (US\$ Millions) and percent gross turnover to community by country. Source: [40].

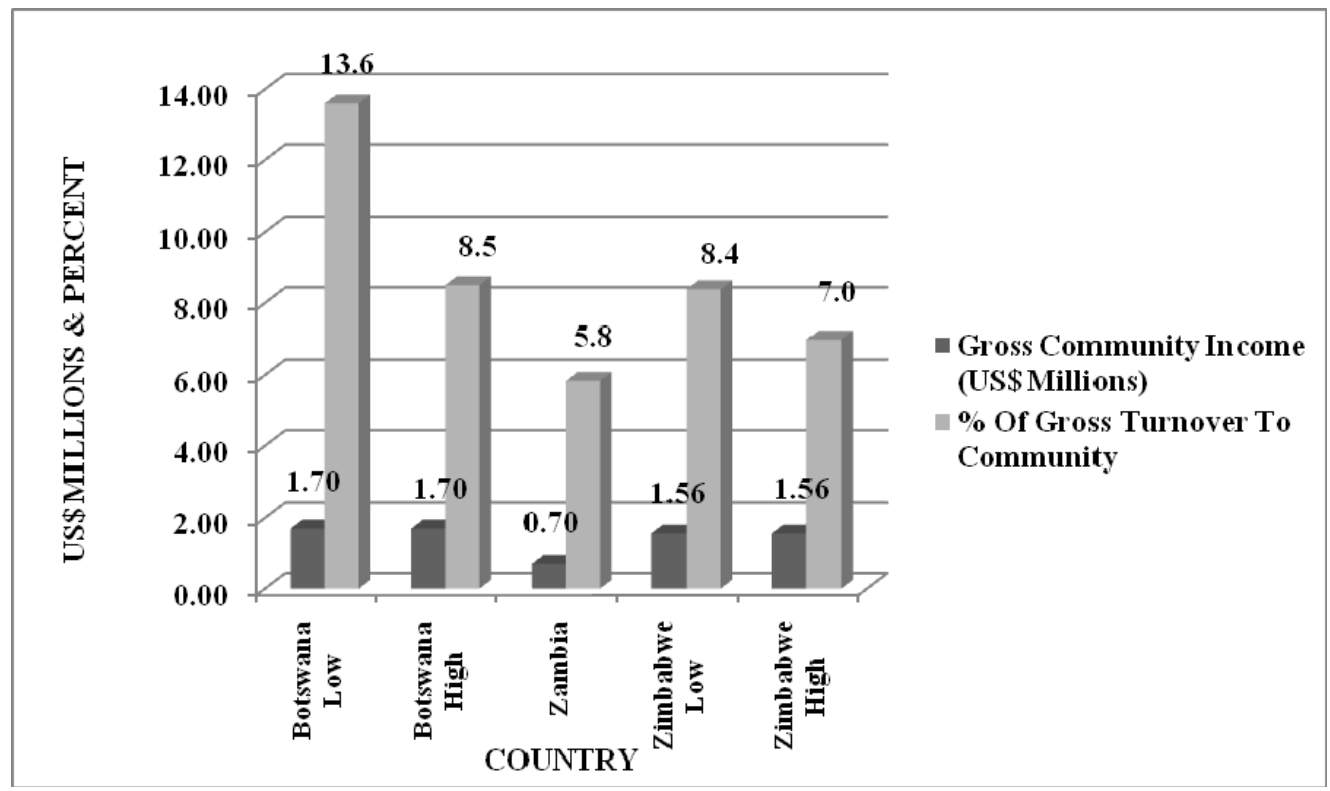

Herein lies another major threat for the future of safari hunting in Sub-Saharan Africa; it being seen as a "White Man's Game". For the most part, the safari operators, professional hunters, and in Southern Africa the game ranchers are white, as are their clients, the overseas trophy hunters. As noted, where black safari operators are involved (e.g., Zimbabwe and Tanzania) they tend to be politically connected, not from the community hunting area with little or no ability to market or run a safari operation. In the case of Tanzania, they tend to sublease, mostly to South Africans, who with 
little long-term commitment have a reputation of shooting areas out of economically valuable trophy quality game and then moving on to the next sublease. This situation is politically untenable. While the Professional Hunters Association of South Africa has made a movement to get more blacks involved, they seem to be taking a very circuitous route by sending them to the Southern African Wildlife College that trains mostly government game rangers, as opposed to the direct route of professional hunting schools. Only the Namibia Professional Hunters Association (NAPHA), in collaboration with Eagle Rock Hunting School, has gone out of its way to train black professional hunters; former trackers and skinners on game ranches. Their next step must be to bring residents of communal hunting areas into the hunting fraternity. Other countries must follow suit [40].

Ultimately, a big difference between the wildlife "revolution" on the private ranches of Southern Africa and "devolution" to date in communal areas is that the landowner on a private ranch pretty much controls, but most importantly is the direct beneficiary of the daily rates and trophy fees from hunting, unless he/she chooses otherwise (sub-contract marketing to safari operator). In the communal areas where CBNRM is practiced, on the other hand, communities are imposed upon and dictated to over what resources can be harvested and required to take on all kinds of middlemen partners (e.g., central and local government, safari/tourism operators and NGOs) to the point that little value accrues to the local level. Failure to bring full devolution to producer communities is a major reason why land uses in many CAMPFIRE areas are incompatible with wildlife (e.g., in-migration, extension of cropping and increased livestock numbers) [111,125] (Figure 5). Most CBNRM programs are stuck in Stage 3, "Wildlife Management With the People", and are held up in attempting to reach Stage 4, "Wildlife Management by the People" by a lack of trained people from the community to operate and manage the complex institutional arrangements, businesses and wildlife/resources at this stage and a reluctance by government to "let the resource go" for philosophical, political and monetary reasons [40].

The tendency of the state preferring decentralization at the level of local government over full devolution to the producer communities) divorces responsibility from authority and entitlement, these programs remaining co-optive rather than empowering, while authority remains firmly held in state hands. This is institutionally fatal, since when authority and responsibility are separated, institutions rarely perform effectively [125,127]. Ultimately, CBNRM generally ignores opportunity costs in favour of a very narrow source of benefits (e.g., primarily safari hunting and some eco-tourism) that generally benefits the community at a higher level (e.g., social infrastructure such as roads schools, clinics, boreholes, grinding mills-common property benefits), but places the traditional entrepreneurs (e.g., hunters, charcoal makers, sawyers, fishermen, honey collectors, thatch grass collectors, wild medicine and food collectors, etc.) at a major disadvantage, often turning them into poachers as a means of supporting their households [128]. CBNRM and its revenue are "carrots" that actually constitute a constraint to accumulation at the level of households, since income from CBNRM at the household level is insignificant, while access to resources in the natural areas and expansion of agricultural land are forbidden because of land use planning restrictions. CBNRM disguises the real dilemma faced by the state, the contradictions of the dualistic nature of colonial property rights; large areas of privately owned white property on the best agricultural lands with large compressed black populations on per capita small over-crowded marginal agricultural lands, often in low rainfall areas [118]. Another important fact that needs to be pointed out, especially in Southern Africa that is undergoing land reform, is that a game ranch that supported one family, when handed over to 100s of 
families will not create a middleclass. The same will hold for agricultural lands, especially if they are subdivided.

Figure 5. Stages towards devolution, community-based natural resource management CBNRM), CAMPFIRE, Zimbabwe Source: Rigava and Chinhoyi [126].

\section{COMMUNITY-BASED WILDLIFE MANAGEMENT}

(A CASE FOR THE CAMPFIRE PROGRAM IN ZIMBABWE)

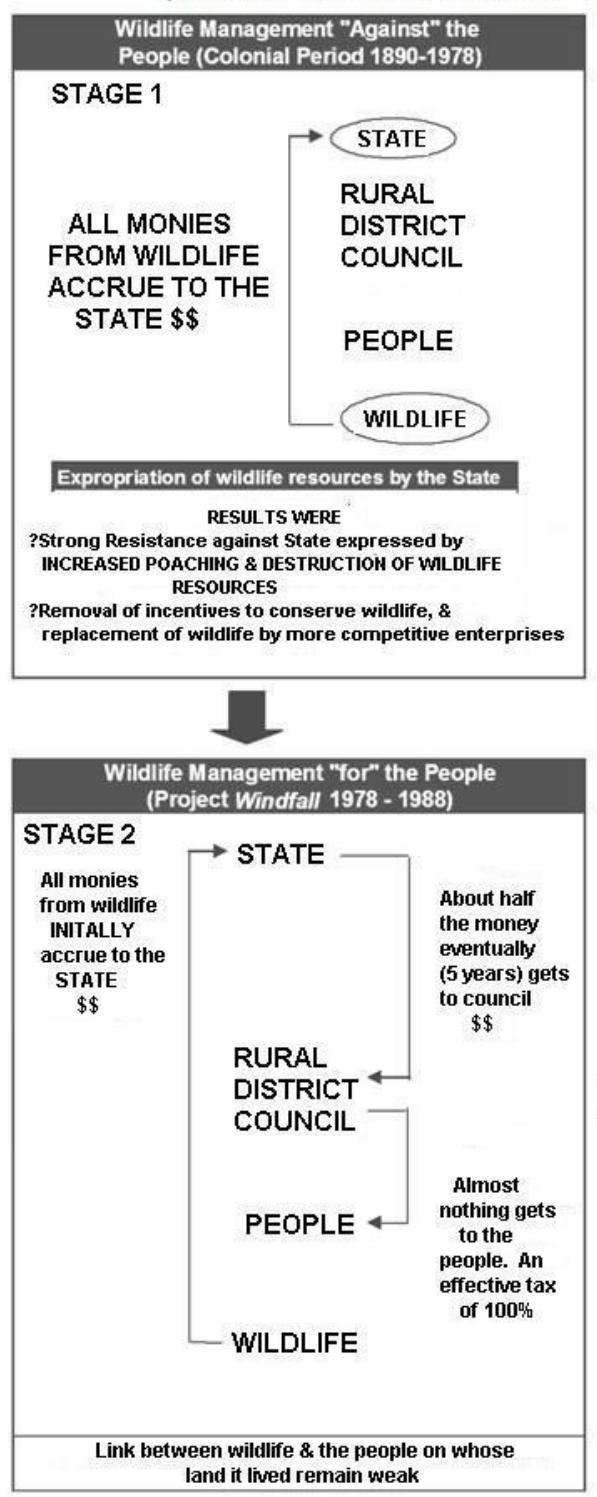

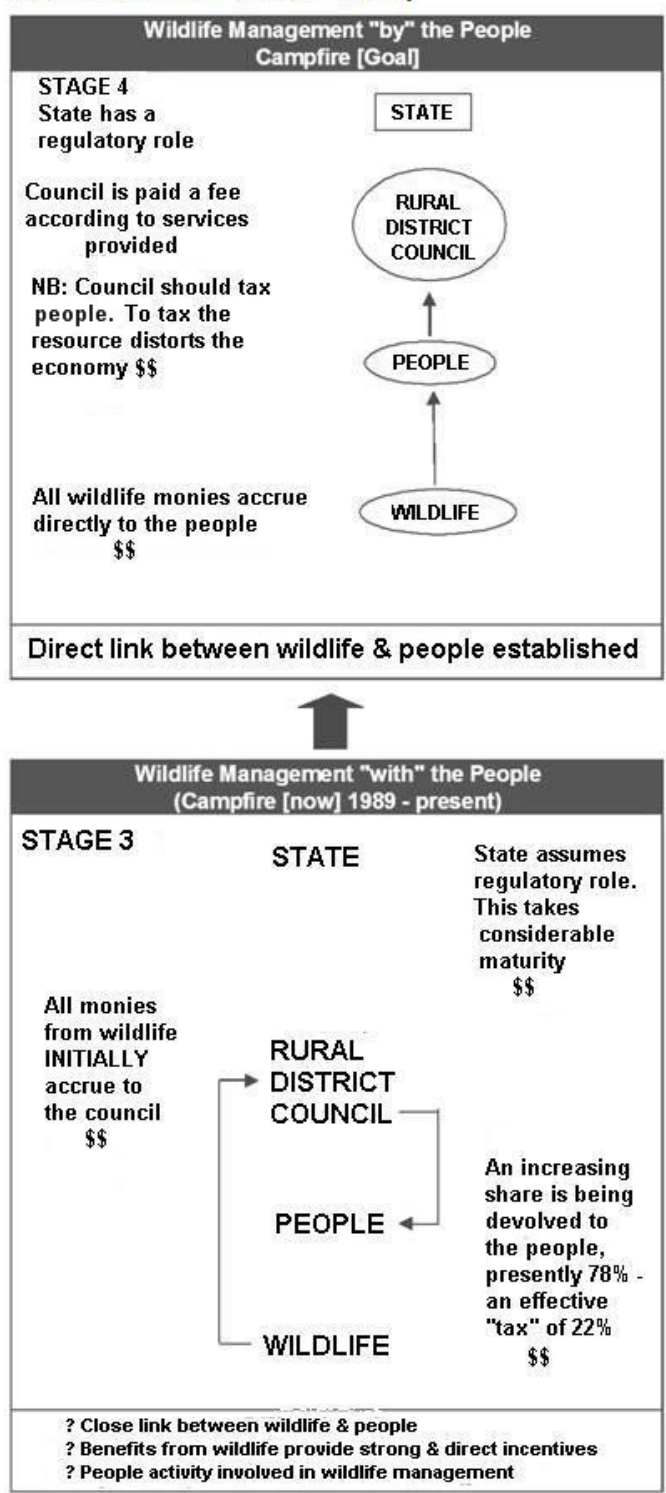

Source: Rigava, Norman \& Champion, Chinhoyi 1997 Zimbabwe Trust

\subsection{CBNRM, Population Pressures \& Land Use-Can Wildlife Compete?}

Meanwhile, Sub-Saharan Africa's population has increased 5.5-6.5 times from 95.9-114 million in 1900 to 622 million in 2000, with projections of between 1.5-1.8 billion people by the year 2050 [40]. At the same time, the livestock population (cattle, goats, sheep, pigs, etc.) increased from 276 to 622 million animals between 1961 and 2003 [40] (Figure 6). The increase in human and livestock 
populations is resulting in encroachment into parks and protected areas, major habitat loss in and outside (often critical rainy season dispersal areas) protected areas, desertification and ultimately the demise of Sub-Saharan Africa's wildlife [40].

Due to the low resource to population ratio, as well as low percentage of benefits distribution, income alone from narrowly focused trophy hunting, as currently distributed, is unlikely to change attitudes towards conservation at the household level, especially among traditional resource users who will continue to poach. What then are potential answers? After the population issue, and education (e.g., taking pressure off the land by preparing youth to compete in a global society), probably the most important shortcoming to CBNRM is a lack of tenure, which is giving ownership back to rural communities of land, wildlife, timber, minerals, fisheries and other resources to be sustainably managed as an important component of African economies and livelihoods.

If parks and protected areas are to have a chance of surviving the $21^{\text {st }}$ century, they will have to serve the interest (primarily development/economic) of the rural impoverished majority, as much if not more than the international elite minority, particularly growing trans-national ecotourism. However, land tenure without resource tenure may be of little value to rural people and may dissuade them from maintaining natural systems and associated biodiversity.

Figure 6. Poverty combined with the increase in Sub-Saharan human and livestock populations in the $20^{\text {th }}$ century is resulting in encroachment into parks and protected areas, habitat loss, desertification and ultimately the demise of wildlife. Source of Photo: Principal author, Fulani herder, Bénoué National Park, north Cameroon, 1998.

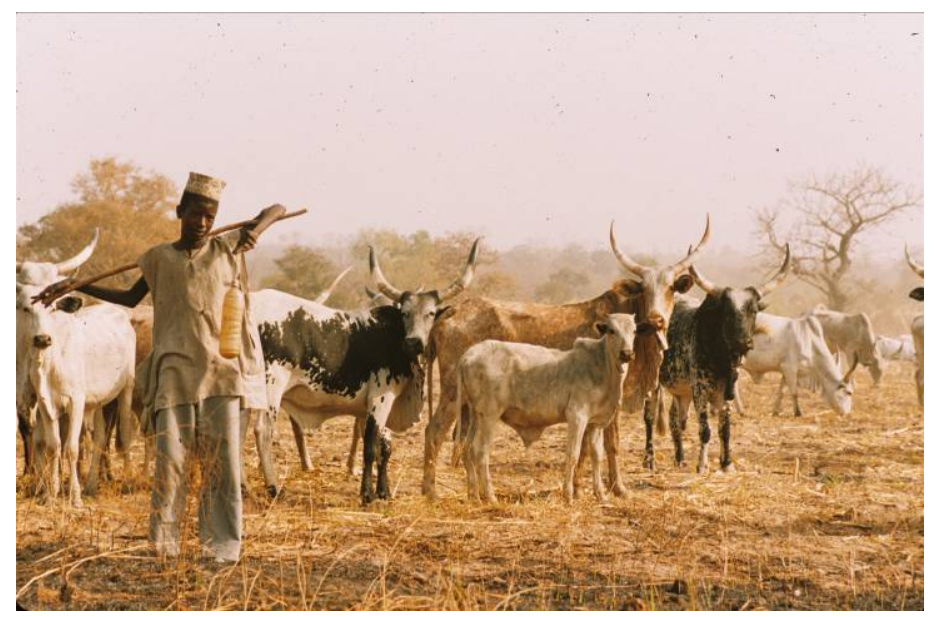

Kenya is a good example, where group ranches own the land, but not the most valuable commodity, wildlife, and are opting for other land uses or selling off the land to be converted into commercial and traditional agriculture that is in conflict with wildlife. In co-existing with wildlife without the potential to maximize economic and social benefits from this resource, group ranches around the Mara are providing hidden subsidies for conservation, including costs of lost production [40]. The average Maasai, seeing no value in wildlife, opted out by selling or leasing his land to commercial wheat schemes or small farmers. These wheat schemes increased from 404,858 ha (1 million acres) in 1981 to $1,214,575$ ha (3 million acres) by 1992 [58]. Many of these areas are critical rainy season dispersal areas for wildlife in the Mara. Large numbers of wildlife that disperse out of the Mara are shot as 
problem animals. One farmer alone shot 3,000 head of game in one year [58]. Also due to the loss of livestock from predators, often coming out of protected areas, without appropriate compensation, and exclusion from lands turned into protected areas without compensation, revenge killings of lion, elephant and rhino over the last 30 years in and around East Africa's protected areas have become fairly common as signs of protest and anger [40]. Waithaka [129] describes the following tendencies with regard to wildlife populations within the Mara Ecosystem that show a consistent decline:

- $56 \%$ overall decline in wildlife for most species in the last 20 years;

- White-bearded Wildebeest (Connochaetes taurinus albojubatus), 81\% decline, 1977-1997, especially in the Loita plains - the main calving and breeding grounds that have been converted to wheat fields;

- Cape Buffalo (Syncerus caffer caffer) decline from 15,400 in the 1970 s to 3,000 in 1994;

- Eland (Taurotragus oryx pattersonianus) from 5,700 in the 1980s to 1,025 in 1996;

- Kongoni/Bubal Hartebeest (Alcelaphus buselaphus cokii) from 4,150 to less than 1,400 over the last 20 years;

- Topi (Damaliscus korrigum) declined from 20,748 in 1988 to 8,900 in 1996;

- Warthog (Phacochoerus aethiopicus) decline by 88\% from 1988-1996; and

- $72 \%$ decline in giraffe (Giraffa camelopardalis), common waterbuck (Kobus ellipsiprymnus) and other antelope from 1988-1996.

This implies that wildlife must pay for its existence, both socially and economically, or risk having its habitat converted to wheat. This will require wildlife and its many uses to be open to a free-market, and/or the conservation community compensating the Maasai landowners in perpetuity for maintaining their ranches as extensions of the Mara ecosystem.

\subsection{CBNRM, Additional Shortcomings}

Additional shortcomings include a number of cases where CBNRM projects have become too top heavy and donor dependent and tend to collapse when the donors pull out [130]. Often benefit streams are dictated by government who most often officially "own" the resource [107,116]. There is little understanding by most communities of wildlife/wild Africa's value and poor negotiating skills to assure a reasonable share in profits. For instance, the inequality that exists between Sub-Saharan Africa's safari industry, mostly run by expatriates and/or whites, can be summed up by a comparison given for areas around the Selous Game Reserve (SGR), Tanzania. The average person works for TZ\$ $600 /$ day, the equivalent of US\$ $0.50-0.60$ /day. The average daily rate for overseas hunters is US\$ 1,500 /day or the equivalent of about six years of local labor working seven days/week [131]. Jealousy from uneven benefit sharing between partners is a threat to sustainability in the development of East African community ecotourism [132]. Such inequalities make it difficult for local people to buy into conservation and can only be overcome with a combination of appropriate policies linked to land and resource tenure giving communities ownership over their resources, along with local people knowing the value of resources so that they can negotiate a rightful share from harvested resources. With the little amount of money that does get to communities, there is often a lack of transparency and 
accountability in the use of these profits, corruption and nepotism being a danger in all Southern African (CBNRM) case studies [133] unless, like any business there is external auditing with the results being made public to the community in order to keep everyone honest [40]. This often shifts the locus of conflict from external to internal, with communities, previously unified in conflict against a common enemy in the form of the state conservation authority, are now divided internally over access to power and benefits [133]. Few opportunities in rural areas for higher level formal education, and the resulting lack of technical and managerial skills by communities contribute to this problem $[97,108]$.

Many of the legal institutions sanctioned and pushed by governments, Western NGOs and donors [e.g., trusts, communal conservancies, communal property associations (CPAs), Wildlife Management Areas (WMAs), Section 21 companies, etc.] under CBNRM that can enter into formal contracts with the private sector run contrary to the customary or informal constitutions that operate in communities and are in conflict with the systems of decision-making in communities that are based on negotiation and consensus-building [117,118], often allowing for more government and NGO control and intrusion over access, to management of, and the right to benefit from a community's natural resources [118,134]. Today's "chiefs" are often appointed by and/or receive a government salary, having more allegiance to the state than to their own people, thus facilitating outside intrusion into what should be local matters. Often communities are too unsophisticated due to many of the above constraints, as well as lacking communications to the outside world, along with knowledge of the marketplace. Thus, they become dependent on middlemen (e.g., safari and tourism operators to undertake their marketing). As concluded in Section 3.2, Table 4 these middlemen, along with governments take the majority of the profits [40]. Often "private sector initiatives such as direct payment of fees for land use, the promotion of wildlife related markets, and the development of joint management projects do have the potential for increasing the local value of wildlife, although they do not compensate for opportunity costs. However, these initiatives may simply be replacing the existing top-down governmental model of conservation, and unless they directly increase landowners' control over the management of their own resources, local communities will remain dependent on these external agencies" [135]. There is a general failure to take into account cultural, ancestral and subsistence ties to wildlife in these protected area management plans that may be as important as material benefits (e.g., meat and money) in assuring the long-term success of conservation [78,92,93]. Ultimately, the intangible psychological liberation provided by communal ownership of land and resources may be as if not more important than the relatively insignificant material benefits on which current CBNRM programs are designed, bringing about the ultimate liberation of the African consciousness necessary to free itself from the shackles of colonialism that will allow South Africa's past President Thabo Mbeki's "African Renaissance" to take place [40]. Only time will tell and right now it is not on the side of wildlife!

Also, as a means of assuring sustainability, there is inappropriate or no monitoring of wildlife off take to assure both economic and ecological sustainability. Often governments, who set the quotas, base them on short-term economic objectives over long-term sustainable conservation. Community members often lack training in appropriate monitoring of relatively easy to collect indices such as trophy quality, hunting effort and hunting success [40]. CBNRM is based upon the philosophical approach of adaptive management as developed in Southern Africa. The adaptive management approach relies on a crude evaluation of wildlife resources based on available data on a specific 
species in order to make conservative estimates of sustainable off-take. This off-take is monitored while data gaps are identified and filled to help make better management decisions on how to best utilize wildlife as an economic and rural development tool for rural Africa. It is based upon a theoretical off-take of only $2-5 \%$ of the annual game population for trophies and another $10-25 \%$ for meat, depending upon the species [40].

Most wildlife monitoring programs in Africa have been dominated by Western researchers and scientists without concern for cost, being propped up by Western donors. They tend to have little or no training in natural resource management, and thus little or no understanding for the kind of biological and physical data needed to make decisions about hunting quotas and other interventions. Very often, expensive aerial surveys are employed with high standard errors, making the information useless for making management decisions. As a means of perpetuating their existence, NGOs often and unnecessarily make themselves indispensible middlemen, since these techniques are beyond the abilities of rural communities. Techniques such as aerial "distance sampling" every third year could be of value in open savannas, if money were available, which tends not be the case unless a donor is funding the effort, and then this is not sustainable since in time the donor will tire and leave. However, on-the-ground monitoring by professional and sport hunters, rural communities and wildlife department officials (e.g., game guards) is believed to be more cost effective, while providing useful information to make informed management decisions [40]. It is highly questionable as to whether total numbers are needed to establish ecologically and economically sustainable quotas for trophy hunting [131].

CBNRM programs such as CAMPFIRE [136,137] and ADMADE [86] have attempted to use adaptive management approaches that include aerial surveys if available, observations by safari operators/local community members and indices such as trophy quality, hunting success and hunting effort (Figure 7) to establish hunting quotas.

Marks [90,91] has used traditional hunters to collect indices of wildlife abundance in the Munyamadzi Corridor, Luangwa Valley, Zambia based upon effort and distance traveled from the village to obtain huntable game. Hulme and Taylor [138] explain that while biologists tend to stratify and systematically count across ecological gradients to count game, local residents go directly to the areas where they know the game occurs. Parker [139] is a strong proponent of using local knowledge to estimate wildlife status. Speaking of Jonathan Kingdon's compilation of data on East African fauna using traditional hunters, among others, Parker [139] states "living among the animals, they knew infinitely more about local distributions than did transient white research boffins”. In 2007, Mr. Ed Phiri of the Zambia Wildlife Authority began a master's degree at Tshwane University of Technology (TUT) in attempt to develop a national wildlife monitoring off take program for trophy hunting.

The lack of adequate alternative livelihood options (e.g., in urban settings), as a means of taking pressure off the rural resource base, is another major problem [40,82,140]. In addition, hunting blocks and eco-tourism areas tend to exclude access to natural resources by community members [40,118]. Meanwhile, rural people are treated as second class citizens by the private sector operating these companies, employing them in low paying low self-esteem positions such as tent boys, trackers and skinners, who at the end of the day are sent off and isolated from clients during meals and other periods of socialization - "labourers and landlords". Other than for the few who are employed in the safari camp, benefits from CBNRM might be considered a form of welfare where you are given money 
for waking up in the morning, which results in passive participation and strong disincentives to work, since community benefits are given for being "observers on the sidelines" rather than players on the field [96,117]. This is less of a problem in ecotourism ventures, where black Africans are employed in higher paying jobs, such as tour guides, "land rover jockeys" that put them in more equitable but less intimate relationships with groups of clients, compared to professional hunting that often relies on developing close one on one ties. Hopefully, many of these shortcomings can be overcome, as CBNRM is a dynamic rather than static process.

Figure 7. Example, triangulation of information in adaptively adjusting quotas in CAMPFIRE areas. Source [136].

\begin{tabular}{|c|c|c|c|c|c|c|c|}
\hline \multicolumn{8}{|c|}{$\begin{array}{c}\text { Quota Sheet 1996: Omay Communal Lands } \\
\text { The proposed } 1996 \text { hunting and cropping quota for } \\
\text { Omay Communal Land }\end{array}$} \\
\hline SPECIES & \begin{tabular}{l|}
1995 \\
Quota \\
\end{tabular} & \begin{tabular}{l|} 
Aerial \\
Survey
\end{tabular} & \begin{tabular}{l|} 
Trophy \\
Quality
\end{tabular} & \begin{tabular}{|l|} 
Safari \\
Operator
\end{tabular} & \begin{tabular}{|c|} 
Community \\
Poaching \\
Information
\end{tabular} & $\begin{array}{l}1996 \\
\text { Quota }\end{array}$ & Comment \\
\hline Elephant Bulls & 20 & $1=$ & -1 & - & 1 & 20 & $8 \mathrm{PAC}$ \\
\hline Elephant Cows & 6 & $1=$ & & $\rightarrow$ & 1 & 10 & $10 \mathrm{PAC}$ \\
\hline Buffalo Bulls & 110 & $\infty$ & $\infty$ & - & tit & 110 & $\begin{array}{l}10 \mathrm{PAC} \text { or } \\
\text { cropping }\end{array}$ \\
\hline Buffalo Cows & 40 & $\infty$ & & - & Itt & 40 & \\
\hline LION & 8 & & & 1 & $\uparrow$ & 6 & \\
\hline LIONESS & 2 & & & 1 & 1 & 2 & PAC only \\
\hline HYAENA & 8 & & & $\uparrow$ & & 4 & \\
\hline CROCODILE & 6 & & - & $\uparrow$ & - & 10 & $\begin{array}{l}\text { Pop. seems to } \\
\text { be increasing }\end{array}$ \\
\hline SABLE & 8 & $-?$ & - & - & - & 10 & \\
\hline BUSHBUCK & 32 & $?$ & - & $\rightarrow$ & $\Longrightarrow$ & 32 & \\
\hline WATERBUCK & 30 & & & 1 & $\uparrow$ & 30 & \\
\hline IMPALA MALE & 910 & $\$+1$ & 1 & † & 14t & 160 & Trophy only \\
\hline Impala Female & 790 & th & & & tft & 40 & Trophy only \\
\hline \multicolumn{8}{|c|}{ KEY TO TABLE } \\
\hline \multicolumn{2}{|c|}{$\begin{array}{l}\text { population } \\
\text { increasing }\end{array}$} & \multicolumn{2}{|c|}{$\begin{array}{c}\text { population } \\
\text { stable }\end{array}$} & \multicolumn{2}{|c|}{$\begin{array}{l}\text { population } \\
\text { decreasing }\end{array}$} & \multicolumn{2}{|c|}{$\begin{array}{l}\text { ? population } \\
\text { changes unknown }\end{array}$} \\
\hline
\end{tabular}

Ultimately, for CBNRM to be successful in its dual goals of both conservation and development there must be significant transfers of power, and the right to directly benefit from the sustainable management of these resources. There will be winners (community) and losers (government, NGOs and private sector). Tenure also can be regarded as the extent to which an individual or community has rights of access to a resource and the degree of those rights [120]. Until full devolution (full community ownership of the land and associated resources) is the official policy, CBNRM, conservation and related development will deal with the symptoms rather than the causes for the failures to date [102]. This implies management rights, decision-making rights for the use of all 
resource(s) on the titled land and the right to benefit from a given natural area by the community stakeholders/interest groups [40,102]; Stage 4 or "Wildlife Management by the People" as indicated in Figure 5. In fact, wildlife utilization as a long-term sustainable land use option can be considered unlikely unless 1) appropriate authority is devolved from the central/local government to the local village(s) level(s) and 2) community wildlife/other resource producers participate in the decisionmaking framework, as active contributors in natural resource management [138] (e.g., becoming involved in wildlife monitoring, quota setting for both customary and safari hunting, anti-poaching, community run hunting and tourism companies, selection of joint venture partners, marketing and negotiating profits, etc.).

This is as opposed to the present situation in most CBNRM programs where governments, the private sector and NGOs make most of the decisions concerning the management of wildlife and its habitat, as well as its marketing, while communities are passive participants. The lack of ownership or tenure over land and resources and their corresponding benefits is a major reason why so many development initiatives have failed over the past decades [125]. Without secure rights of access to natural resources, rural people will not have a long-term interest in managing them or participating in CBNRM. Fear not that somehow communal ownership of wildlife will result in it becoming "open access" and less secure. In fact, tenure rights based on membership in culturally based local groups are often more secure than those based on freehold tenure or leasehold introduced and backed by the state [125]. Communal ownership works best where traditional authority is still strong (e.g., the chief represents the interests of his people over that of central government, and traditional management systems still exist such as hunting guilds, taboos, totems, etc.), so that customary management rules can be fostered and built upon [108]. Ultimately, secure tenure over, or clear user rights to land and natural resources is of crucial importance if rural people are to manage their resources, since it determines the linkages between responsibility and authority over land and natural resources, and also determines the incentive structures for sustainable use [108]. Unless this land issue and its tenure can be resolved, the feasibility of CBNRM comes into question [130]. Similar to private game ranches in Southern Africa, the success of CBNRM initiatives may largely depend on legal ownership over wildlife [130], timber, mineral and other resources where community structures obtain the majority of the benefits from partnering with the West to use their extractive technologies, while, like any entrepreneur, paying taxes to the government [40].

\subsection{Transfrontier Conservation Areas, CBNRM on Steroids Displacing Rural Communities}

A key supporter of CBNRM in the 1980s and early 1990s, USAID in southern Africa made a dramatic switch between 1996 and 1997 from CBNRM in favour of supporting Transboundary Natural Resource Management (TBNRM)/Transfrontier Conservation Areas (TFCAs) as the result of critical reviews over the lack of success with CBNRM and the questioned role of social sciences and community considerations in conservation and biodiversity. They were prepared to support "back to the barriers" conservation in favour of community involvement [141]. NGOs have jumped on the band wagon, as a means of accessing large sums of money under the globalization process where concern for "global commons" has become a driving force encroaching on rural people, resulting in a new form of imperialism [142] on a grander scale than CBNRM. The State and NGOs seek to establish TFCAs 
for a number of political reasons; promoting regional peace, pooling resources to overcome economies of scale and consolidation of key ecosystems that cross political boundaries, including wildlife migration corridors. They are energized by "romantic ideals of recreating Eden and the Myth of Wild Africa" where wildlife roams free, supported by revenue from a Mecca of tourism free of immigration requirements. NGOs get government buy-in and then use their political influence and expertise to fund such programs. These NGOs hold a lot of power due to their access and control over money and their access to power elites within governments [143].

As in CBNRM concern exists that few benefits will accrue to rural communities due to "the high amount of leakage in the tourism industry with a large percentage of earnings, wages and profits remitted/retained away from the area". As in CBNRM, local communities risk to lose further through changing land uses, resulting in loss of access to traditional natural resources on which they depend economically for sustenance and for cultural purposes. Ultimately, these programs bypass working with communities to better manage and sustainably use their natural resources "conservation" in favour of strict ecological interests "preservation", usurping community benefits and rights. In other words, it becomes business as usual for the Western conservation movement and Sub-Saharan African elite, centralizing control over land and resources, as during the colonial and postcolonial era, as opposed to devolution. NGOs facilitate the state in usurping traditional land and resource tenure [142] using the legal system and international donor support. Recent initiatives in southern Africa include:

- The Great Limpopo Transfrontier Park (Gaza-Kruger-Gonarezhou Transfrontier Conservation Area (TFCA).

- The Four Corners (Near Victoria Falls where Zimbabwe, Namibia, Zambia and Botswana meet).

- ZIMOZA (Zimbabwe-Zambia-Mozambique Transboundary Area).

The goal by the end of the $21^{\text {st }}$ century is for TFCAs to account for the world's largest biodiversity zones [144].

There is concern the Makuleke could lose their contractual park land-a portion of Kruger National Park, South Africa that they won back in the 1990s, as well as over the future of the 20,000 rural poor in Mozambique's side of the Gaza-Kruger-Gonarezhou TFCA (now called Great Limpopo Transfrontier Park) [143]. Likely, as during colonial times, and as all too frequent in Western donor/NGO driven conservation in the $21^{\text {st }}$ century-this will be imposed conservation, against the will of local communities. The conceptualization and agreement in the creation of the Greater Limpopo Transfrontier Park took place without any consultation with local communities, while empowering the state as owner of the land and resources, not the local community-thus no real empowerment $[143,144]$. By 2003, only two workshops had been held with the elected community committee responsible for the five million people living in the area. Forty percent of the households in the Mozambican portion of the Great Limpopo Transfrontier Park never heard of the TFCA concept and of their involvement, resulting in an $\mathrm{NGO}$ /donor driven top-down process [142]. Already, the Mozambican government is using heavy handed repression against local hunters "poachers", with plans to move the 6,000 residents outside of the park. Plans are to leave residents along the Olifants River alone. The north and south portions of the park will be used for tourist hunting (sport hunting) to 
generate income for community development and to operate the park, since ecotourism is not expected to be significant [40]. There is concern that in the to-be-fenced (wildlife in and people out) Sengwe corridor of Zimbabwe, villages will be moved to make way for "Wild Africa" that tourists wish to see, resulting in loss of the most fertile land along rivers, pools and pans critical to both people and livestock, wildlife, forest products such as the liala palm used in handicrafts and community reserve land used for "expanding households, and strategic relocation as a result of conflict, witchcraft accusations, feuds, and general misunderstanding". Relocating communities onto formerly commercial farms, which the bankrupt Zimbabwean government cannot support (e.g., extension and startup costs), will socially dislocate them from the cross border network of communities who have learned to depend on each other for a flow of resources and commodities necessary for survival in a subsistence economy. Establishment of border posts, an armed bureaucracy and formalization of mobility (customs) may actually impede the fluid movement of local people and resources across borders, central to the livelihoods in this region of southern Africa, and end up as detrimental to the communities [144]. In essence, TFCAs are forcing rural local people into voiceless partnerships with the state and NGOs backed by Western donor funding [143].

Along the frontiers of Southeastern Cameroon, Congo Brazzaville and the Central African Republic, a new form of colonization began at the end of the $20^{\text {th }}$ century in an invasion by commercial logging companies, Western conservation NGOs and safari operators linked to the transnational Lake Lobeké/Dzanga-Sangha/Nouabalé-Ndoki “Tri-National De La Sangha” National Park that crosses these three borders. Funded by international donors, Nelson [145] calls this vast takeover of traditional territories by Western conservationists, "Corporate Conservation". Concern has even been raised that WCS is in collusion with a major German logging company as a means of expanding its protected area of Nouabalé-Ndoki, while the German logging company attempted to no avail to use WCS as a front to push the idea of obtaining a "green label" for sustainable logging, such as through FSC (Forest Stewardship Council) [146]. The project area overlaps the traditional farming, hunting and gathering lands, supporting thousands of Baka Pygmies and Bantu ethnic groups. There is concern that this is leading to the imposition of new rules affecting access to forest resources on which their livelihoods are based, "concordant with a systematic pattern of community neglect and marginalization observed in the management of other parks in Cameroon" [145]. Local communities have not been involved in planning for these efforts carried out by national and international elites in isolated capital cities [145]. The Indigenous Peoples of Africa Coordinating Committee (IPACC) at the 33rd Session of the African Commission on Human and Peoples' Rights (ACHPR)/Niamey-Niger 15-29 May 2003, have raised concern that conservation and development programs initiated through the "Congo Basin Initiative, the African Partnership for Forests, the Africa Forest Law Enforcement Group and the New Partnership for Africa's Development (NEPAD), are all likely to intensify this carve up of indigenous peoples' forests into protected areas and logging zones without the rights of indigenous peoples being taken into account" [60]. 


\section{Innovative Attempts to overcome Shortcomings of CBNRM}

\section{1. “Project Noah”, Training Rural Africans, In Wildlife Management}

Project Noah grew out of a scholarship initiated in 1999 to a Maasai student from Kenya sent to Tshwane by Tony Dyer, the doyen of professional hunters and Gilford Powys, the largest private landowner in Kenya, and one of the founders of the infamous Galana Ranching Scheme. Project Noah is an educational and training program run in collaboration with the international hunting fraternity. This program has as its main goal the education and training of rural youth from wildlife rich areas throughout Sub-Saharan Africa in the sustainable utilization and conservation of wildlife and associated habitats. It also exposes them to the value of wildlife and how it can serve as a powerful economic and rural development tool. This training takes place at the Department of Nature Conservation, Tshwane University of Technology (TUT), South Africa. Through the education and training of students and establishing them back in their countries of origin, it is believed that the following objectives are being achieved:

- Sensitizing rural communities to the ecological and economic importance of their natural systems, and to develop the capacity within these communities to sustainably manage wildlife;

- Maintaining (develop) wildlife as a viable and alternative land use option in Africa outside parks and protected areas;

- Assisting in the development of grass roots democracies whereby rural communities can gradually take over ownership, management and the right to benefit from their wildlife and other natural resources;

- Eventually influencing wildlife utilization policy (bottom up approach);

- Creating a core of scientific expertise where students will become the future community wildlife managers, safari operators, government decision makers, or conservation NGO coordinators;

- Ensuring that the utilization (hunting) of wildlife in Africa remains (becomes) a viable option of income generation, thereby ensuring that future generations of sport hunters can continue to practice their sport.

Other objectives include:

- Establishing a network whereby graduated Noah students can have access to a decision support system (Housed at the Department of Nature Conservation at Tshwane University Of Technology) whereby technical and scientific support will be rendered to former students, their communities and decision makers;

- Eventually developing long-term ties with the various host countries and regional wildlife training institutions such as Mweka/Pasiansi and Garoua wildlife colleges, respectively in Tanzania and Cameroon. 
Upon completion of their training, the idea is to plant Noah graduates back into their communities where they can integrate their new found knowledge into traditional management systems in finding an African solution to conservation that integrates rural Africans into a multiple-resource use conservation model, seen as an important component of the way forward [40]. To date over 50 students from all of the major hunting countries in Africa have been provided with scholarships supported by the international sport hunting fraternity, including Shikar Safari Club, Dallas Safari Club and Safari Club International. The success of this program can be determined from the fact that the majority of these students have returned to their countries and/or communities and are actively using their new found skills and insight into the wildlife trade to further conservation and community development. Already, key lecturers from both Mweka and Pasiansi wildlife colleges are working on master and doctoral degrees, further cementing relationships between TUT and these educational institutions. Examples of some of the students to graduate from this program that link TUT to rural communities, educational institutions and game departments across the subcontinent include:

\section{Botswana}

- Tlhokomelang Ngaka, diploma in nature conservation working on a B-Tech thesis, "Can indigenous knowledge be incorporated into modern conservation systems"? First San woman to study nature conservation at a tertiary level. She is from the ancient Anikhwe or River Bushmen tribe, and grew up in the north-west of Botswana, in Ngamiland.

- Matota Teko is from the Yei Tribe with a diploma in nature conservation back working in the Okavango Delta, Botswana.

\section{Burkina Faso}

- Yaya Ouattara, diploma in nature conservation, applying for B-tech. Chosen by the Dozo hunting community that is currently managing the 125,000 ha Comé-Leraba Reserve in Southern Burkina Faso.

\section{Cameroon}

- Heribert Ndjanga, second year nature conservation student, a young Tikar hunter from the village of Kong, Cameroon, where he is head of all traditional matters including access to wildlife and other natural resources in the surrounding forests.

- Armand Biko'o, completed diploma, B-Tech and masters in nature conservation; thesis "Conservation status determination of the rare and endemic plant Haworthia koelmaniorum var. mcmurtryi". Head of Cameroon Natural Resources (CAMNARES) that helps rural communities market their natural resources and lecturer at UNISA (University of South Africa), a distance education university.

- Maliki Birosse Wardjomto completed diploma and B-Tech, near completion of master's degree entitled "Fine Scale Habitat Selection of White Rhino in Songinvelo". Comes from the vicinity of Bénoué, Boubandjida and Faro national parks, northern Cameroon. Interested in the plight of the black rhino and wild dog/lycaon in this region. Active member CAMNARES. 


\section{Kenya}

- Joel Ole Nyika, Maasai with diploma in nature conservation, masters degree from an English university, currently working in community development.

\section{Namibia}

- Paulus Arnold, diploma in nature conservation, Bushmen/San working in Tshumkwe West Bushmanland, Namibia as assistant landuse planner and nature conservationist.

\section{Tanzania}

- Edward Lengai Mbarnoti, diploma in nature conservation, working on a B-Tech. Works with Maasai pastoralist groups. Has served as a research assistant to Dr. James Ingoe from Department of Anthropology, University of Colorado at Denver assessing the progress of WMA's (Wildlife Management Areas) around Tarangire National Park, Southern Maasailand.

- Billy Munisi, graduated with diploma in nature conservation. Research technician at College of African Wildlife Management, Mweka where he has assisted many international researchers from America and Europe. His passion is ornithology.

- Gladys Joseph Lendii, Maasai, diploma in nature conservation working with Maasai as a field officer in community development.

- Benson Obdiel Kibonde, B-Tech in nature conservation and nearing completion of master's thesis entitled "Poaching and Extent of Human-Wildlife Conflicts in and around Wildlife Areas in Tanzania: Case study of Selous Game Reserve and its Buffer Zone." Longest reigning Chief Warden of the Selous Game Reserve and currently head Pasiansi Wildlife College, Tanzania.

- Ladislaus Kahana, working on doctorate "The Ecology of Glade Edges: The Case of Mount Meru Game Reserve" Lecturer, College of African Wildlife Management, Mweka, Tanzania.

- Honori Thomas Maliti, completed master's thesis, "The use of GIS as a tool in wildlife monitoring in Tanzania: A case study on the impact of human activity on wildlife in the Tarangire-Manyara ecosystem". Researcher, Tanzania Wildlife Research Institute (TAWIRI).

- John Kaaya, working on master's thesis, “Developing cost effectiveness in monitoring strategy for wildlife populations in Tanzania". Formerly with TAWIRI, currently headquarters, Ivory Room, Wildlife Division, Tanzania.

\section{Zambia}

- Andrew Chomba, finished his B-Tech on the spatial distribution of black rhino in North Luangwa National Park, Zambia, where he is chief game ranger, as well as responsible for surrounding hunting blocks. His masters will be a continuation of his B-Tech, "Availability and Usage of Black Rhino Habitat in the North Luangwa National Park".

- Andrew Nkole, B-Tech Thesis: "An assessment and comparison of perceptions in conservation in three chiefdoms - Zambia”. Area Warden, Chunga/Kafue National Park for the Zambia Wildlife Authority (ZAWA). He worked under the well known ecologist Richard Bell who pioneered one of the early community programs linked to trophy hunting. 
- Edward Phiri, B-Tech and now working on Master's degree entitled: "Institutionalizing quota setting through monitoring safari hunting in Zambia". Currently, park ranger, Directorate of Conservation and Management, Mosi oa Tunya Area Management Unit Livingston, Zambia.

- Macamwala Zeko Simwanza, B-Tech in nature conservation working on Master's degree entitled: "Accountability and governance of community resource boards in Zambia's Game Management Areas (GMAs)". Responsible for natural resource protection and community awareness in the Zambia Wildlife Authority (ZAWA).

\section{Zimbabwe}

- Joseph Mundawu, diploma graduate and second year B-Tech in nature conservation. A former school teacher, handpicked by CAMPFIRE Association. Joseph was managing director of Ngala Safaris, Chirdedzi, Zimbabwe, but fled Zimbabwe, as a result of the economic collapse under the Mugabe regime. He hopes by the time his B-Tech is over, things will have changed and he can return to pursing his life's dream of owning a safari company linked to rural communities.

- Simon Steyn, diploma in nature conservation and working on B-tech thesis: "Assessment of community perceptions over land invasions in Gonarezhou National Park, Zimbabwe". From the Chiredzi region of Southeastern Zimbabwe. A former school teacher, handpicked by the CAMPFIRE Association.

\subsection{Finding African Solutions to African Problems}

Two of the more interesting follow-up but nascent community development and conservation programs that TUT's department of nature conservation is involved in include Cameroon and Burkina Faso, linked to chasse libre or self-guided hunting, whereby an overseas sport hunter is guided by a traditional hunter from the local community. This form of hunting is possible, mainly in Francophone countries, where highly skilled traditional hunters can act as hunting guides without having to procure a formal professional hunters license. There is no reason why this practice should not be expanded to East and Southern Africa, other than legal constraints would have to be overcome, something that may not be in the interest of the entrenched governments or the professional hunting fraternity. Chasse libre requires minimal investment by the community, since the sport hunter covers all costs from food to vehicle rental. The sport hunter comes self-sufficient, including camping gear. As communities build up infrastructure and services, they can slowly increase their fees (e.g., vehicle rental). Spending a day before and after the hunt in the village, guided by traditional hunters and getting to know them around the campfire, the visiting sport hunter and community members have as much a cultural as hunting experience. Most importantly, it provides local community members with the pride and dignity that tends to escape them in expatriate run programs, using basic counterinsurgency principles in conservation that provide them control over their destiny as a result of feeling ownership over and having the ability to control access to "their" natural area and its resources. 


\section{Chasse Libre with Tikar Hunters, Cameroon}

In the case of Cameroon, students from TUT formed an NGO (non-governmental organization), CAMNARES (Cameroon Natural Resources). Its ultimate aim is to contribute to conservation by empowering local communities, overcoming poverty and creating autonomic structures for the sound management and sustainable use of natural resources. CAMNARES acts as an intermediary between sport hunter and the traditional hunters from the community. It communicates with overseas hunters via email, takes deposits, helps them through the airport on arrival and departure, assures that all trophies and skins are properly treated, stored boxed and shipped, arranges all trophy export documentation and acts as a buffer between the client and often stifling bureaucracy. For these services, it charges a fee. The first pilot program is being undertaken with the village of Kong, about 1.5 hours north of the old German capital of Yoko. The Tikar ethnic group fled the Fulani jihad on the Adamawa Plateau in the 1800's to this transitional area between the savannah and the dense humid lowland forests of the Congo Basin. Forgotten about by the Germans, French and Cameroon government until a few years ago with the declaration of the Mbam and Djerem National Park that they border, the village of Kong has a forest of several hundred thousand hectares that they consider theirs. No one goes into the forest without the permission of the chief and elders. They have a land use plan for the area with sections for traditional hunting and other areas they protect until a sport hunter arrives. Non-selective snaring is disallowed, while only selective hunting is condoned with 12 bore bolt action shotguns locally made from the steering wheel shafts of old Landrover vehicles. Bongos (Tragelaphus euryceros) are not hunted, as they are known to have great monetary value for sport hunting. The overseas client can also hunt the forest buffalo (Syncerus caffer nanus), western forest sitatunga (Tragelaphus spekei gratus), giant forest hog (Hylochoerus meinertzhageni), red river hog or bushpig (Potamochoerus porcus pictus), yellow-backed duiker (Cephalophus sylvicultor), and various other duiker species, while in the savannah area sing sing waterbuck/kob defassa (Kobus defassa unctuousus), kob/cob du buffon (Kobus kob kob) and warthog (Phacochoerus africanus fosser) are also hunted. The goal of CAMNARES is to work with community resource users to establish a land use and resource off take monitoring program, getting as much income from the areas as possible. In addition to wildlife, agriculture, eco- and cultural tourism, timber, fish and wild foods offer potential household level income generating opportunities. To date one of this program's strengths is avoiding the pitfalls of becoming donor dependent. A student from Kong has received a 2008 scholarship from Shikar Safari Club to study nature conservation at TUT (Figure 8, student, Heribert Ndjanga $3^{\text {rd }}$ from viewer's right looking at the picture). 
Figure 8. Traditional Tikar hunters with chasse libre client empowered to take control over and manage their natural resources, Kong, Cameroon. Source: Principal author, 2005.

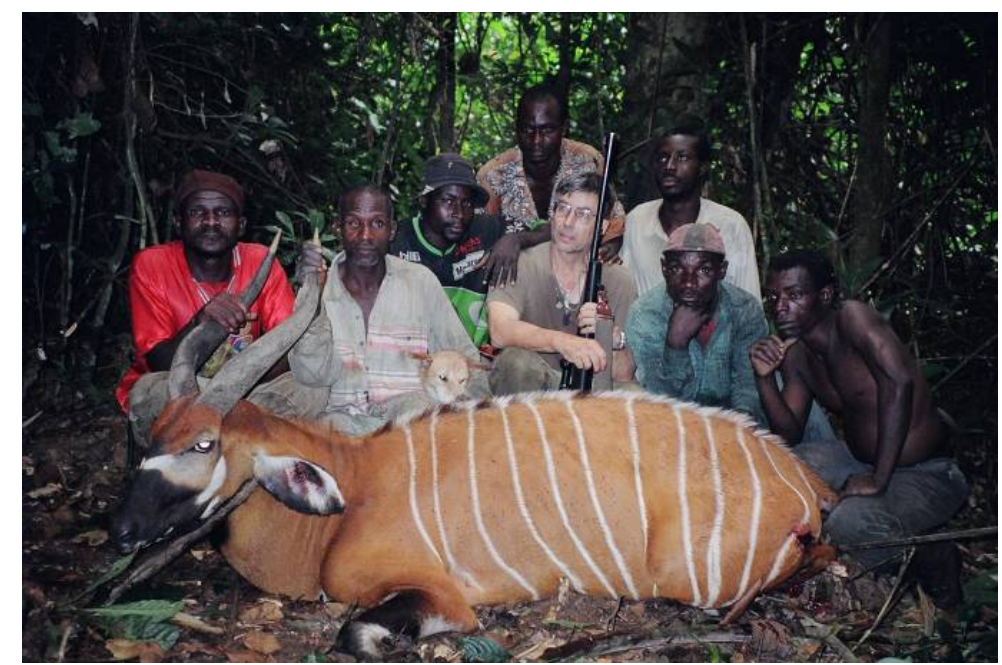

Shortcomings unique to this program include: 1) the need to become an officially recognized Village Hunting Area, 2) the need for retention of all trophy fees by the community to assure an adequate share in the revenue stream that is currently taken by the government (Table 5); 16 as opposed to $28 \%$ of the gross turnover if the trophy fee is retained, falling close to the recommended community $33 \%$ capture of gross turnover [123], 3) the need for a detailed resource and land use plan, 4) need for monitoring of resource harvests to assure sustainability, 5) the need for more youth trained at university level in nature conservation, 6) assuring a democratic structure within the community to determine employment in nature conservation, and to determine 7) how communal income from resources should be distributed.

The relationship between CAMNARES and the community is developing into a true partnership. The community is taking an active role in both guiding the tourists, developing a multiple-resource use management plan and undertaking anti-poaching of "their" area, many of the reasons being related to the intangible aspects of conservation as mentioned above that impact on the psychological wellbeing of both the community and individuals within. There are plans to open a furniture factory to employ community members in the transformation of forest products from the area.

\section{Chasse Libre with Dozo Hunters, Burkina Faso}

The 125,000 ha Comoé-Leraba Reserve is located in Burkina Faso, on the border with the Ivory Coast, $530 \mathrm{~km}$ southwest of the capital, Ouagadougou. Since 2003, traditional Dozo hunters have been undertaking anti-poaching and guiding overseas sport hunters. The Dozo hunter/warriors are also the standing army for Conté in Guinea, rebels in the Northern Ivory Coast, and manage the peripheral zones in the new Park of Upper Guinea (Figure 9). 
Figure 9. Dozo hunter warriors empowered to conduct anti-poaching and guide overseas trophy hunters. Source: Principal author, Folonzo, Burkina Faso, 2003.

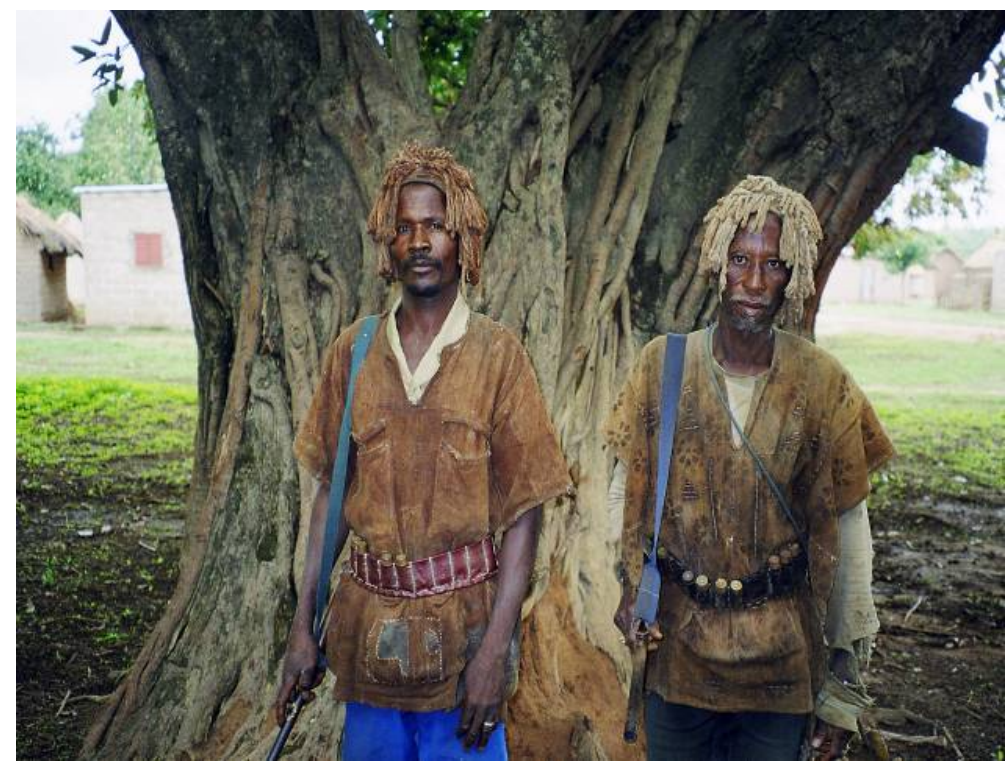

Table 5. Income distribution per hunt from self-guided community hunting in West Africa per hunt.

\begin{tabular}{|c|c|c|c|c|}
\hline \multirow[b]{2}{*}{ COST } & \multicolumn{2}{|c|}{$\begin{array}{l}\text { CAMNARES PILOT ONE } \\
\text { HUNTER + CAMERMAN }\end{array}$} & \multicolumn{2}{|c|}{$\begin{array}{l}\text { BURKINA FASO CHASSE } \\
\text { LIBRE PROGRAM, } 2002\end{array}$} \\
\hline & $\begin{array}{c}\begin{array}{c}\text { Bongo hunt } \\
\text { (Euro) }\end{array} \\
\end{array}$ & $\begin{array}{c}\text { Percent gross } \\
\text { turnover }\end{array}$ & $\begin{array}{c}14 \text { Day } \\
\text { buffalo hunt } \\
\text { (Euro) }\end{array}$ & $\begin{array}{l}\text { Percent gross } \\
\text { turnover }\end{array}$ \\
\hline HUNTING LICENSE & 769 & & 185 & \\
\hline TEMPORARY RIFLE IMPORT PERMIT & 451 & & 185 & \\
\hline CERTIFICATE D'ORIGINE & 69 & & 6 & \\
\hline VETERINARY CERTIFICATE & 46 & & ? & \\
\hline BLOCK RENTAL (Government Daily Rate) & 923 & & & \\
\hline DAILY RATE (Community Fee) & 1,185 & & 862 & \\
\hline TROPHY FEE BONGO & 1,539 & & - & \\
\hline $\begin{array}{l}\text { TROPHY FEE BUFFALO—ASSUME } 1 \\
\text { BUF/PERSON/HUNT }\end{array}$ & - & & 692 & \\
\hline TROPHY FEE ROAN & - & & 462 & \\
\hline GOVERNMENT ECO-GUARDS & 923 & & - & \\
\hline GOVERNMENT FEES CAMERAMAN & 1,539 & & & \\
\hline $\begin{array}{l}\text { BENEFITS TO GOVERNMENT (without/with trophy } \\
\text { fee) }\end{array}$ & $4,720 / 6,259$ & $37 / 49$ & 376 & 7 \\
\hline $\begin{array}{l}\text { COMMON PROPERTY BENEFIT ( } 2 \\
\text { TROPHIES/HUNT) \&/or COMMUNITY FEE }\end{array}$ & - & & 2,016 & \\
\hline $\begin{array}{l}\text { TOTAL EMPLOYMENT FOR COMMUNITY (8-14 } \\
\text { people/hunt) }\end{array}$ & 867 & & 549 & \\
\hline $\begin{array}{l}\text { TOTAL COMMUNITY BENEFITS (without/with } \\
\text { trophy fee) }\end{array}$ & $2,052 / 3,591$ & $16 / 28$ & 2565 & 47 \\
\hline CAMNARES FEES & 2,462 & 19 & & \\
\hline $\begin{array}{l}\text { OTHER COSTS (vehicle, fuel, hotels, food, airfare } \\
\text { ticket, tips, etc.) Lower figure occurs if airfare, hotels } \\
\text { and trophy shipment excluded to make it is more } \\
\text { comparable to Table } 4\end{array}$ & $1,910-2,910$ & & $2,536-4,535$ & \\
\hline $\begin{array}{l}\text { TOTAL COST OF TRIP (Minus airfare, hotels and } \\
\text { trophy shipment) }\end{array}$ & 12,683 & & 5,477 & \\
\hline
\end{tabular}


The origin of the Donso (Dozo) hunting guilds date back to the 1236 A.D. under the Malian Mandingo Empire of Sundiata Keita. They consider themselves professional. Their hunting garb consists of an earthy dyed tunic and a special wig-like headgear. The apprentice hunter "donso dewn" and his hunting over a 3-6 year period are controlled by the "master hunter" or "donsofa, donsokoutigui or kalanfa".

The uniqueness of this program is that the government has turned over the management and operation of the reserve to the peripheral community, numbering 17,000 people in 17 villages. A community organization, AGEREF, oversees reserve management and hunting trips. In 2002 TUT placed one of its students with this village, for her practical year, to help them with development of a land use plan, wildlife monitoring and marketing. The community also selected a student from the community (Yaya Ouattara) who has graduated from TUT with a diploma in nature conservation, is back working in his community and has plans to pursue his bachelor's degree. In addition to income from trophy hunting, money is generated from leasing fishing rights and honey collection. In the 2004-2005 season, the community netted about \$US 25,000 from chasse libre, and US\$ 5,000 from 10 tons of fish [40]. Unique shortcomings to this program include: 1) though capturing $47 \%$ of the gross turnover, income of only US\$ 7-10/household/year from chasse libre, 2) government must legislate the trophy fee going to the community so that it becomes permanent and 3) heavy dependence on outside financing from the World Bank, with potential destabilization once funding ends. One advantage this program has over the one in Cameroon is that the community gets to keep the trophy fee. Although not believed to be an issue in this case, the program and its possible expansion should be monitored to assure a de facto army does not develop as is believed to have happened in neighbouring Guinea Conakry with the National Hunters Association of traditional hunters that was originally established to manage protected areas and control hunting [134,147], as well as the role traditional hunters have played in civil wars in Sierra Leone, Liberia [40,147], and the Ivory Coast [40].

A common problem with both TUT chasse libre programs is inadequate ties to the market place. An option exists to undertake a joint venture for 10-15 years with a seasoned safari operator with the understanding that community members are taken overseas on marketing trips and receive training in professional hunting. However, in the short-run the community will not necessarily be financially better off unless they are capable of negotiating a rightful share of net profits. The risk is that the expatriate safari operator will take the daily rate, leaving the community with only individual employment, possibly the trophy and/or conservation fee, while being relegated back to second class citizens in the safari camp. An expatriate safari operator was brought on for the 2009 season in the Burkina Faso program. It is unclear where this program is heading; destined to become another topdown expatriate-driven hunting block, or one where the traditional Dozo hunters and community actively participate in the management of wildlife/resources, in running the safari company, and in determining access to other resources in the area. Hopefully, as these communities become more sophisticated and offer more services (e.g., provide their own vehicle, food and camping gear); they can up their daily rates and salaries and start marketing to a higher paying clientele. 


\subsection{Conservation and CBNRM on Their Own Fail}

Due to low resource/population ratios and the narrow focus on trophy hunting, CBNRM is part of the solution to conservation and development, but on its own will fail. Because of low resource/population ratios, even if expanded to a multiple resource model, on its own, it will likely not create a middleclass in rural Africa. About $70-75 \%$ of Sub-Saharan Africa is comprised of savannah biome. Its best land use is as pasture for wildlife and livestock, but while marginal, is increasingly being used by itinerant farmers in search of new lands as fallow periods disappear across the subcontinent due to soaring human populations. This is resulting in severe environmental degradation and a zone of conflict, often between pastoralists and farmers, from Senegal to Darfur, Sudan along the Sahelian/Saharan borders, and within and between countries like Rwanda/Democratic Republic of Congo, Sudan/Chad/Central African Republic, and Kenya/Somalia [40]. In all instances, wildlife loses. Both Thomson [148] and Parker [139] see a direct relationship between human population increases and wildlife/habitat declines. This is readily seen in Kenya, where human populations are increasing at $3 \%$ per annum and wildlife is decreasing at 3\% per annum [149]. Norton-Griffiths [149] estimates the total loss of large wildlife in Kenya since 1977 at 60-70\%, with equal amounts being lost within and outside of protected areas. In next door Tanzania, wet season populations of the most numerous wildlife in the Tarangire-Manyara ecosystem, wildebeest (Connochaetes taurinus) concentrated largely in the Simanjiro plains east of the park during this period, have declined from a high of 43,539 in 1988 to 5,257 in 2001, while cattle have increased during the same time frame from 53,828 to 240,842. This latter figure is ten times higher than the most abundant wildlife species in 2001, the zebra at a wet season population of 25,280 (41,073 in 1988). Farm plots increased from 1,051 in the wet season of 1988 to 49,114 during the wet season of 2001 in the Tarangire-Manyara ecosystem, largely in the Simanjiro plains east of Tarangire National Park, impacting the migratory routes of wildlife, especially wildebeest [150]. This is not unique to Maasailand, but is happening across the subcontinent as people opt for other land uses. For instance, in 2004, there were an estimated 1,000 +/300 buffalo and 22,500 +/- 2,500 cattle in the Moyowosi South hunting block of western Tanzania. The largest herd of buffalo observed was about 400, whereas 20 years ago herds of up to 6,000 buffalo were commonly observed [40].

While many tourists with no point of reference marvel at the abundance of wildlife in East Africa, well known safari operators Robin Hurt and Fred Duckworth in their mid to late 60s, who grew up in Kenya and are still active in East Africa, estimate that wildlife populations in Kenya and Tanzania are $25 \%$ of what they were in their youth; a $75 \%$ reduction in numbers [40]. Due to man and the increase in his livestock, wildlife today makes up only $10 \%$ of the large herbivore biomass in Southern Africa [151].

Sadly, unless the value of wildlife to rural communities drastically increases, agriculture may win out in areas where it currently has a comparative economic advantage such as the Maasai Mara dispersal areas in Kenya [139] and Lake Mburo National Park [70] in Uganda. Once the mean annual rainfall exceeds 600 millimetres in this region, wildlife will have a difficult time out-competing the same land converted to agriculture [152], especially high altitude grasslands such as are found in Tanzania (e.g., Serengeti/Maasailand) and Kenya (e.g., Mara). This transformation has already occurred in the high altitude grasslands of South Africa, displacing wildlife in favour of maize 
production [40]. In fact, it is estimated that more than $50 \%$ of Kenya's higher potential land ( $>700 \mathrm{~mm}$ annual rainfall) has already been converted to agriculture that displaces wildlife, but is inclusive of livestock [149].

In addition, the authors believe a critical factor in taking pressure off the rural resource base, is for Sub-Saharan Africa to go through the same urbanization, industrialization and information technology (IT) evolution/revolution experienced by Europe and North America in the $20^{\text {th }}$ century, where, for instance, less than $2 \%$ of the people in America feed the majority living in urban centres. Hara [153] explains how IMF/World Bank structural adjustment policies (SAPs) resulted in the collapse of local manufacturing industries and the shrinking of the manufacturing sector, forcing people to turn back to living directly off of the natural resource base in Malawi, especially the fisheries. This placed undue pressure on the resource base and made the co-management of fisheries between government and the fisher community very difficult. Hara [153] explains that the success of limiting access to a resource will depend on the general economy acting as a sink of excess labour. As long as employment in other economic sectors remains low and living directly off of natural resources (e.g., soil, wildlife, fisheries, forest and non-forest products) remains the main source of livelihoods, as opposed to transforming natural resources in industry and agro-industry, attempts to assure the sustainable use of resources will be difficult and co-management or sustainable management through devolution of authority to rural communities is unlikely to be successful. Given the population explosion of the $20^{\text {th }}$ century and the fact that the current population is expected to more than double again by 2050, conservation, be it CBNRM or fortress conservation, is doomed to failure on its own unless linked to an urbanization/industrialization process [40].

At the same time, it believed that rural communities must be allowed to capture more wealth from the truly valuable resources in "their" natural areas, sustainably managing them as "green factories" not just for wildlife but also for tropical hardwoods, strategic minerals, oil, fisheries, wild medicines and foods, etc. This also implies transformation of these resources through "decentralized urbanization" in order to avoid developing mega-cities [40], mainly African capitals that concentrate people and place unsustainable pressure on local resources, especially water.

Currently, South Africa is the only industrialized country transforming significant numbers of products on the subcontinent capable of taking advantage of a gradual opening up of trade with the West through programs such as the African Growth and Opportunity Act (AGOA). Sub-Saharan Africa has the unique renewable and non-renewable resources desired by the West (e.g., Democratic Republic of Congo contains $80 \%$ of the world's reserves of strategic mineral COLTAN ${ }^{\mathrm{x}}$ necessary to make capacitors that manage the flow of current in electronic devices from cell phones, computers and stereos to videocassette recorders) [40]. Some call the region of Central/Southern Africa, encompassing the DRC, Zambia, Zimbabwe and South Africa, the "Persian Gulf of Strategic Minerals of our Earth" [154]. The governments of Sub-Saharan Africa must start dictating conditions of use, requiring industrialization and transformation of resources on the subcontinent, as opposed to the current situation of exporting most natural resources in the raw. In essence, this is already happening to a large degree in South Africa, locally called "beneficiation", and its expansion must continue. To avoid the pitfalls of globalization, much needed foreign direct investment (FDI) must provide salaries based upon purchasing power parity (PPP) ${ }^{\mathrm{xi}}$ and address environmental issues both in and outside the 
workplace to assure sustainability so as to prevent the pollution and slums such as seen around the Athi River industrial area that borders Nairobi [40].

\subsection{A Parting Shot}

The following are anecdotal experiences of the principal author in his 30 years of living across Sub-Saharan Africa. They need no discussion, but in essence epitomize the difficulties discussed above that rural and urban Africans face living in a survival mode, which must be overcome before the average African can be concerned for long-term conservation and biodiversity goals so desired by Western urbanized societies.

Fouta Djallon Mountains, Guinea Conakry

Due to increasing populations, decreasing agricultural production and increasing desires to enter into a moneyed economy, wildlife was being mined as a short-term resource. In many instances in these isolated mountain communities, wildlife was more valuable than agriculture faced with poor infrastructure, acidic, low nutrient lateritic soils and declining fallow periods. In the mid-1980s, while environmental advisor to the Gambia River Basin Development Organization (OMVG), the principal author helped well known chimpanzee researcher Janice Carter obtain a research permit to setup in the Fouta Djallon Mountains. The Fouta Djallon Mountains are often called the Château d'Eau or "West Africa's water reservoir" since they are the primary source of water for major rivers such as the Gambia, Senegal and Niger. The exploding human population and resulting deforestation was resulting in the chimpanzee populations becoming fragmented in isolated pockets of forest surrounded by farm land. Ms. Carter wished to study the consequences of this phenomenon with regards to its potential to isolate breeding populations of chimps, associated genetic implications if this isolation resulted in inbreeding and ultimately the long-term viability of these populations. On an invited visit to her camp site to meet with local lion hunters who worked for her, the principal author spent half a day praying with them, cleansing his body with holy water washed into a calabash from writings on a Koranic board using a bird quill and black off an iron pot. As one Fulani Marabou lion hunter explained,

"You may think it wrong of me to hunt lion for a living. You get paid every two weeks down in the big city in your air-conditioned office. For one lion skin, I get what I make out of the ground in a year (poor lateritic soils). You can put me in jail but when I get out, I will do it again. I have a wife and children to feed. You have one of two choices if you wish me to stop. You can shoot me now or find me another way of life" [155].

Bwindi "Impenetrable Forest", Uganda

Under pressure from USAID, the $331 \mathrm{~km}^{2}$ Bwindi National Park was created in 1991 out of what had been sustainably managed as both a forest and gorilla reserve. With one exception, in one of the most densely populated areas in Africa (140-500 persons $/ \mathrm{km}^{2}$ and an average of only 0.7 ha of land available per person on steeped sloped terraced soils), the people respected the forest boundary. The 1965 Parks Act prohibited people from entering the park, an exclusion zone [69]. In 1992, when the 
principal author accompanied Dr. Fred Kayanja, Trustee of the East African Wildlife Society and Vice Chancellor of Mbarara University of Science and Technology, he explained to the people that they would be compensated for not being able to use the Park's resources, by having schools, clinics and roads built for them. Pit-sawing was the major source of income from the forest. A single tree is cut, a pit dug, and with a two-man saw-one man on the tree and one in the pit - boards are made on the spot and carried out on foot paths. It is labour intensive, providing important income to heads of families, while no logging roads are required which fragment the forest and open it to uncontrolled access. In fact, in the book The mountain gorilla: Ecology and behaviour by Schaller [156], it was suggested that with the disappearance of the forest elephant, some pit-sawing could be beneficial to the gorillas by opening up the forest and providing the luxuriant vegetation they needed for food. What Schaller failed to mention is that until the coming of the European and his $7^{\text {th }}$ century Norman concept of exclusion zones, people have always played a pivotal role in determining the ecology of the Impenetrable Forest and most other ecosystems in Sub-Saharan Africa. Now that key mega-fauna are extinct from the forest, a person's role, contradictory to what most people think, becomes that much more critical if the gorilla and its habitat are to survive. Wild and Mutebi [157] explain,

"At Bwindi the activities of buffalo (now extinct) and elephant (now very few) caused disturbed secondary habitats which gorillas prefer. Secondary vegetation is now common in the forest due to timber harvesting. With better protection the forest is regenerating, and gorilla habitat is likely to decline. The level of plant use established at BINP (Bwindi National Park) is far below the impact needed to maintain secondary habitats at their present extent and causes less vegetation destruction than tourist trails cut daily for gorilla viewing".

Most importantly, as one pit sawyer explained to Dr. Kayanja's evaluation team,

"Your schools, clinics and roads are well and good, but they don't fill empty bellies or pay school fees. We want access to the forest" [69].

Wild and Mutebi [157] site similar reactions from local communities. To date it appears that about $20 \%$ of the park has been opened to the collection of minor forest products $[157,158]$, but not to labour intensive pit sawing. At the same time

"Under pressure from traditional Western conservationists, who had come to believe that wilderness and human community were incompatible, the Batwa (Pygmies) were forcibly expelled from their homeland" [62].

Munyamadzi Corridor, Zambia

While the principal author was visiting the Munyamadzi GMA (Game Management Area) during an evaluation of ADMADE for the Zambian government and USAID in July/August 1992, four poachers were brought into the camp by the village scouts (Figure 10).

The ringleader was an old man in his 60s. His history might be considered as typical of many "poachers" who today transition back and forth between urban and rural areas. He started his life as a 
miner in the Copper Belt of Zambia. He claimed that as a miner he often "dreamed" of hunting, which might be interpreted as a dream summons from his ancestors as explained in Marks [15,89]. He was involved in a mining accident and returned to his home in the vicinity of Mpika in order to rehabilitate. While there, an elephant got into a field and his uncle gave him a muzzleloader with which he killed the elephant. He reported this incident to the chief and was given the meat. After a month of recuperation, he returned to the mines. This was 1965 .

In 1972, he stopped working in the mines after a number of near fatal accidents that caused him to fear for his life. He began hunting for the pot after that. He met a businessman near Ndola who had an elephant license and who hired him to go into the Machiya Fungulwe GMA to shoot his elephant. He did this twice, finding out how lucrative elephant hunting can be. He began purchasing his own elephant licenses from Lusaka and shooting elephant in order to sell the meat in Lusaka. He did this three times. Then in, 1974, he joined a "Senegalese poaching ring" that smuggled ivory. He worked with them through 1986 when the Senegalese were thrown out of the country. He had been caught several times in the Munyamadzi GMA, as recently as January 1992. He claimed that if he was not in the bush for two to three months, his body stiffened and that he got the urge to hunt. If he could get a job like going with the scouts, it would make him happy and keep him busy. He explained that if put in jail for two years, he would likely return to poaching on his release. Three young boys apprenticing under him were urban poor:

- The 17 year-old said he didn't know what he was getting into and that he only went along because he had been told to do so;

- The 19 year-old had been poaching with the old man since 1987; and

- The 23 year-old had been poaching with the old man since 1991.

Figure 10. Poachers, elephant hunter and young apprentices, apprehended by ADMADE game guards, Munyamadzi Corridor, Luangwa Valley ZAMBIA, 1992. Source: Principal author.

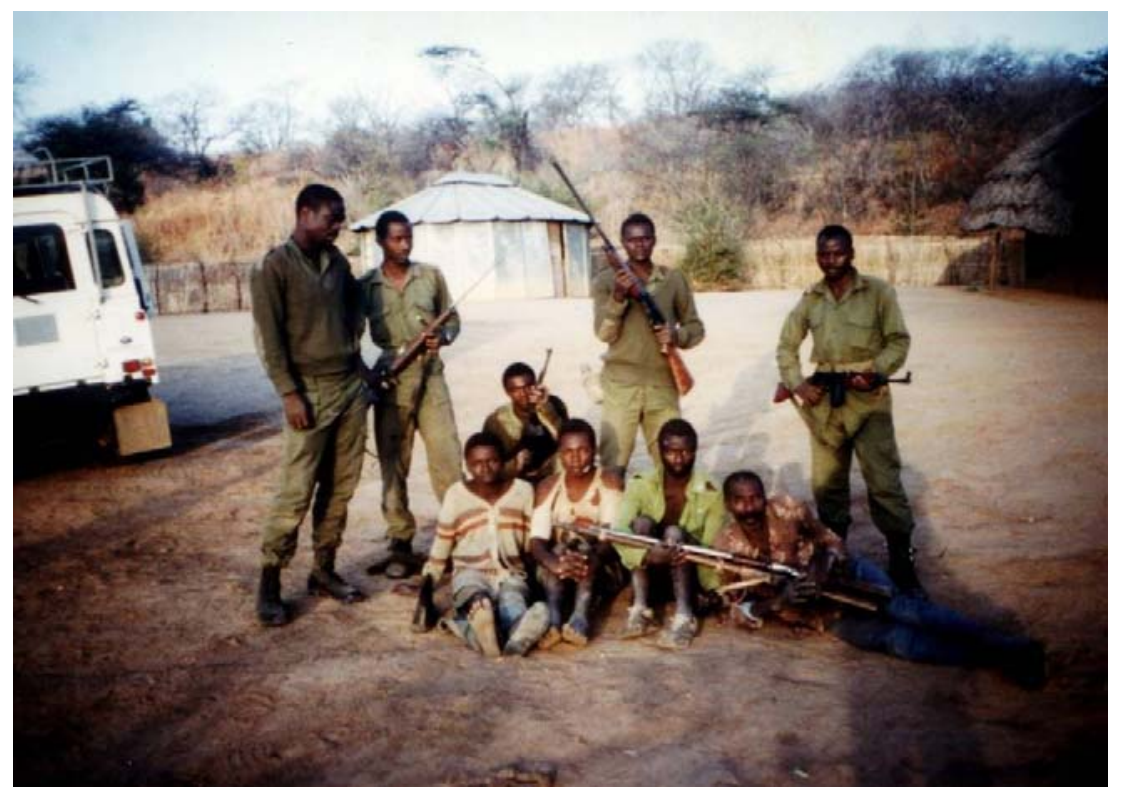


This is the first time any of these young men had been caught for poaching. The game scouts, who were interviewed throughout the evaluation, agreed that prison was not the solution. Similar to the lion hunters in Guinea, the game scouts said, "We have one of two choices, either shoot them or help them find viable long-term employment" [40].

\section{Conclusions}

Sub-Saharan Africa is potentially the only continent where man and mega-fauna co-evolved, both playing an important role in ecosystem management. Colonialism changed this relationship, disenfranchising rural Africans from their natural resources. Hunters and other resource users were turned into poachers, resulting in impoverishment, increasing malnourishment and an alienation from Western philosophies of conservation. This process continues, previously in the name of conservation and today "biodiversity" and ecotourism. Beginning in the late 1970s, community based natural resource management programs (CBNRM) evolved in Southern Africa in an attempt to provide benefits to rural Africans as a means of winning them over to this modern conservation approach. These programs tend to be donor/NGO driven and narrowly focused on safari hunting, ignoring the multitude of resources within these natural areas. Benefits tend towards common property, being insignificant in most cases at the household. Old colonial ties are maintained between black government elites and a predominantly white safari/tourism controlled industry who between them abscond the majority of profits. Rural Africans, who will determine the future of wildlife and their natural systems, must have a more active stake in the "wildlife game", both economically and psychologically. Land and resource tenure are at the heart of the matter.

As farmers are subsidized in America for setting land aside as wetlands, is it possible that subsidized payment of "opportunity costs" by the global community directly to communities will be required to offset the conversion of these areas to other land uses (e.g., maintaining threatened dispersal areas to parks in the Maasai ecosystem of Kenya/Tanzania, maintaining dense humid lowland forests in the Congo Basin for both biodiversity and as a carbon sink to absorb $\mathrm{CO}_{2}$ produced by the industrialized world)? In the long run, as the subcontinent develops, intangible benefits (cultural and ancestral ties, feeling of ownership over land and resources, and control over destinies), as in North America and Europe, may be the most important determinants in the future of wildlife and its habitat compared to the Western biased "meat and money" on which CBNRM is based; key factors often ignored by African governments, Western donors and NGOs. This assumes land and resource ownership are returned to rural communities. Regardless, due to the low resource to human population ratio in rural Africa, helping communities capture more of the income from trophy hunting, expanding multiple resource use benefits to the community, increasing household wealth and/or using community income to send youth off for tertiary education, as a means of competing in a global world, could be key catalysts to improving CBNRM. However, on their own these actions will fail unless linked to a decentralized urbanization/industrialization process, as a means of avoiding developing mega-cities that beneficiates these mostly rural resources in their country of origin, employs more people and ploughs the generated wealth back into the development of the region and country as a whole.

In closing, the authors, one a son of Africa (Reilly) and the other whose father comes from Africa (DeGeorges), wish to wake up the world's conservation community to the fact that they are far from 
saving wildlife through creating exclusion zones, disenfranchising Africans from their lands and resources, and in sharing with them the meagre proceeds provided from trophy hunting. Unless Africa is allowed to evolve beyond a welfare state dependent upon foreign aid that in turn provides raw products to the economic benefit of the rest of the world while its people live in abject poverty, in trying to survive Africans will not have the luxury of caring for and taking stewardship over these unique resources. The 21 st century will see the ultimate demise of the vast wide open space that to Westerners is "Wild Africa", but to Africans currently serves as their supermarket, hardware store, pharmacy and for many a key source of their livelihoods. Unless creative actions are taken, with a more than doubling of the population in the next 50 years, the shelves in these stores, with few exceptions, risk to be emptied and a treasure trove of biodiversity and unique cultures lost to humankind.

\section{References}

1. Diamond, J. Collapse. How societies choose to fail or succeed; Viking Penguin: New York, NY, USA, 2005.

2. Brantingham, J.P. Hominid-Carnivore coevolution and invasion of the predatory guild. $J$. Anthropol. Sci. 1998, 17, 327-353.

3. Burkhardt, J.W. Herbivory in the intermountain West. An overview of evolutionary history, historic cultural impacts and lessons from the past; Station Bulletin 58 of the Idaho Forest, Wildlife and Range Experiment Station College of Natural Resources: University of Idaho, Moscow, ID, USA, 1995.

4. Denevan, W.M. The pristine myth: The landscape of the Americas in 1492. Annals Assoc. Am. Geogr. 1992, 82, 367-385.

5. Grayson, D.K. Late Pleistocene mammalian extinction in North America: Taxonomy, chronology, and explanations. J. World Prehistor. 1991, 5, 193-232.

6. Leakey, R.; Lewin, R. The sixth extinction. Biodiversity and its survival; Orion Books: London, UK, 1995.

7. Martin, P.S. Refuting late Pleistocene extinction models. Dynamics of Extinction; Elliot, D.K., Ed.; John Wiley \& Sons: New York, NY, USA, 1986.

8. Martin, P.S. 40,000 years of extinctions on the 'planet of doom'. Paleogeography, Paleoclimatology, Paleoecology 1990, 82, 187-201.

9. Steadman, D.P. Prehistoric extinctions of Pacific island birds: Biodiversity meets zooarchaeology. Science 1995, 267, 1123-1131.

10. Child, G. Growth of modern nature conservation in Southern Africa. Parks in transition. biodiversity, rural development and the bottom line; Child, B., Ed.; Southern African Sustainable Use Group (SASUSG)/IUCN. Earthscan: London, UK; Sterling, Virginia, USA, 2004; pp. 7-17.

11. Cullis, A.; Watson, C. Winners and losers: privatizing the commons in Botswana; Securing the Commons No. 9. SMI (Distribution Services) Ltd.: Stevenage, Hertfordshire, UK, 2005.

12. Dadnadji, K.K.; van Wetten, J.C.J. Traditional management systems and integration of small scale interventions in the Logone floodplains of Chad. In Towards the wise use of Wetlands; 
Davis, T.J., Ed.; The RAMSAR Library: Gland, Switzerland, 1993. Available online: http://www.ramsar.org/lib/lib_wise.htm\#cs7 (Accessed 7 July 2009).

13. Hinz, M.O. Without chiefs there would be no game. Customary law and nature conservation; Out of Africa Publishers: Windhoek, Namibia, 2003.

14. Mariko, K.A. Le monde mysterieux des chasseurs traditionnels. Agence de Cooperation Culturelle et Technique; Les Nouvelles Editions Africaines: Paris, France; Dakar, Senegal; Abidjan, Ivory Coast; Lomé, Togo, 1981.

15. Marks, S.A. The imperial lion. Human dimensions of wildlife management in Central Africa; Westview Press: Boulder, Colorado, USA, 1984.

16. Njiforti, H.L.; Tchamba, N.M. Conflict in Cameroon. Parks for or against people? In The law of the mother. Protecting indigenous peoples in protected areas; Kemf, E., Ed.; Sierra Club Books: San Francisco, USA, 1993; pp. 173-178.

17. Claridge, G.C. Wild bush tribes of tropical Africa. An account of adventure and travel amongst pagan people of tropical Africa, with a description of their manners of life, customs, heathenish rites and ceremonies, secret societies, sport and warfare collected during a sojourn of twelve years; Seeley, Service: London, UK, 1922.

18. Hagberg, S. The authority and violence of a hunters' association in Burkina Faso. Each bird is sitting in its own tree. In Conflicts over land and water in Africa; Derman, B., Odgaard, R., Sjaastad, E., Eds.; James Curry: Oxford, UK; Michigan State University Press: East Lansing, USA; University of KwaZulu-Natal Press: Pietermaritzburg, South Africa, 2007; pp. 187-201.

19. Ibo, G.J. Perceptions et pratiques environnmentales en milieu traditionnel Africaines: L'exemple des societes Ivoiriennes anciennes; ORSTOM, Centre de Petit Bassam: Abidjan, Ivory Coast, 1994.

20. Parker, I.; Amin, M. Ivory crisis; Chatto and Windus: London, UK; Camerapix Publishers International: Nairobi, Kenya, 1983.

21. Traore, D. Restitution des resultants de l'enquete dur la gestion traditionnelle de la chasse. Cas specifique des Dozo; Ministere de L'Environnment de L'Eau, Secretariat General. Direction Generale des Eaux et Forets, Direction Regionale de L'Environnment et des Eaux et Forets des Hauts-Bassins. Direction Provinciale de L'Environnement et des Eaux et Forêts de la Comoé. Service Provincial Faune: Chasse, Burkina Faso, 2000.

22. McGregor, J. Living with the river. Landscape and memory in the Zambezi Valley, northwest Zimbabwe. In Social history and African environments; Beinart, W., McGregor, J., Eds.; James Currey: Oxford, UK; Ohio University Press: Athens, OH, USA; David Phillip: Cape Town, South Africa, 2003; pp. 87-105.

23. Solly, H. "Vous etes grands, nous sommes petits". The implications of Bulu history, culture and economy for an integrated conservation and development project (ICDP) in the Dja Reserve, Cameroon; Original thesis presented in view of obtaining a Doctorate in the Social Sciences. Free University Of Brussels. Faculty of Social sciences, politics and economics Centre for social and cultural anthropology: Brussels, Belgium, 2002.

24. Wannenburgh, A.; Johnson, P.; Bannister, A. The Bushmen; Struik: Capetown, South Africa, 1979. 
25. Hitchcock, R.K. Hunting is our heritage: The struggle for hunting and gathering rights among the San of Southern Africa. In Parks, property and power; Anderson, D.G., Kazunobu, I., Eds.; Senri Ethnological Studies 59. National Museum of Ethnology: Osaka, Japan, 2001; pp. 139-156.

26. Ritter, E.A. Shaka Zulu. The biography of the founder of the Zulu nation; Penguin Books: New York, NY, USA, 1955.

27. Boone, C. Political topographies of the African state. Territorial authority and institutional choice; Cambridge University Press: New York, NY, USA, 2003.

28. Hakimzumwami, E. Community wildlife management in Central Africa: A regional review; Evaluating Eden Series, Discussion Paper No 10. International Institute for Environment and Development (IIED): London, UK, 2000. Available online: http://www.iied.org/pubs/pdfs/ 7804IIED.pdf (Accessed 8 July 2009).

29. Hitchcock, R.K. We are the First People: Land, natural resources and identity in the Central Kalahari, Botswana. J. South. Afr. Stud. 2002, 28, 797-824.

30. Hitchcock, R.K. Sharing the land: Kalahari San property rights and resource management. In Property and equality. Ecapsulation, commercialization, discrimination; Widlok, T., Tadesse, W.G., Eds.; Berghahn Books: London, UK, 2005; Vol. II, pp. 191-207.

31. Hitchcock, R.K. Land, livestock, and leadership among the Ju/'hoansi San of North Western Botswana. Anthropologica 2003, 45, 83-88.

32. Marshall, L. The Kung of Nyae Nyae; Harvard University Press: Cambridge, MA, USA, 1976.

33. Moorehead, R. Changes taking place in common property resource management in the inland Niger delta of Mali. In Common property resources: ecology and community based sustainable development; Berkes, F., Ed.; Belhaven Press: London, UK, 1994.

34. Schmidt, J. Influence des acteurs externs sur leas Baka sans la region Lobeké. Etude de Cas. MINEF Cameroon and GTZ PROFORNAT (Projet de Gestion des Forets Naturelles): Yokodouma, Cameroon, 1998.

35. Smith, A.B. Pastoralism in Africa. Origins and development ecology. C. Hurst: London, UK, 1992.

36. Hitchcock, R.K. Traditional African wildlife utilization: Subsistence hunting, poaching and sustainable use. In Wildlife conservation and sustainable use; Prins, H.H.T., Grootenhuis, J.G., Dolan, T., Eds.; Kluwer Academic Publishers: Boston, MA, USA, 2000.

37. Turnbull, C. The mountain people. The classic account of a society too poor for morality; Triad/Paladin Grafton Books: London, UK, 1972.

38. Dublin, H.T. Dynamics of the Serengeti-Mara woodlands. An historical perspective. Forest and Conservation History 1991, 35, 169-178.

39. Kjekshus, H. Ecological control and economic development in East African history. The case of Tanganyika, 1850-1950; Heinemann Educational Books: London, UK, 1977.

40. DeGeorges, P.A.; Reilly, B.K. A critical evaluation of conservation and development in Sub-Saharan Africa; The Edwin Mellen Press: Lewiston, New York, NY, USA, 2008.

41. Carruthers, J. The Kruger National Park. A social and political history; University of Natal Press: Pietermaritzburg, South Africa, 1995. 
42. Maddox, G. 'Degradation narrative' and 'population time bombs': Myths and realities about African environments. In South Africa's environmental history. Cases and comparisons; Dovers, S., Edgecombe, R., Guest, B., Eds.; David Philip Publishers: Capetown, South Africa, 2002; pp. 250-258.

43. MacKenzie, J.M. The empire of nature. Hunting, conservation and British imperialism. Studies in imperialism; Manchester University Press: Manchester, UK, 1997.

44. Dorst, J. Before nature dies; Collins \& Sons: London, UK; Houghton Mifflin Co: Boston, MA, USA, 1970.

45. Pringle, J.A. The conservationists and killers. The story of game protection and the Wildlife Society of Southern Africa; T.V. Bulpin and Books of Africa: Cape Town, South Africa, 1982.

46. Cattrick, A. Spoor of blood; Standard Press Limited: Cape Town, South Africa, 1959.

47. Wels, H. Fighting over fences. Organization co-operation and reciprocal exchange between the Save Valley Conservancy and its neighbouring communities in Zimbabwe; Vrije University: Amsterdam, The Netherlands, 2000.

48. Giles-Vernick, T. Cutting the vines of the past. Environmental histories of the Central African rain forest; The University Press of Virginia: Charlottesville, VA, USA, 2002.

49. Baldus, R.D. Wildlife conservation in Tanganyika under German colonial rule; TanzanianGerman Development Cooperation: Dar es Salaam, Tanzania, 2001. Available online: http://www.wildlife-programme.gtz.de/wildlife/download/colonial.pdf (Accessed 9 July 2009).

50. Funaioli, V.; Simonetta, A.M. Statut actuel des Ongules en Somalie. Mammalia 1961, 25, 97-111. In Before nature dies; Dorst, J., Ed.; Collins \& Sons: London \& Glasgow, UK, 1970.

51. Adams, W. Nature and the colonial mind. In Decolonizing nature. Strategies for conservation in a post-colonial era; Adams, W., Mulligan, M., Eds.; Earthscan Publications: London, UK, 2003; pp. 16-50.

52. Anderson, D.; Grove, R. Conservation in Africa: People, policies and practice; Cambridge University Press: Cambridge, UK, 1987.

53. Bond, I.; Child, B.; de la Harpe, D.; Jones, B.; Barnes, J.; Anderson, H. Private land contribution to conservation in South Africa. In Parks in transition. Biodiversity, rural development and the bottom line; Child, B., Ed.; Earthscan Publications: London, UK, 2004; pp. 29-61.

54. Gibson, C.C. Politicians and poachers. The political economy of wildlife policy in Africa; Cambridge University Press: Cambridge, UK, 1999.

55. Neumann, R.P. Imposing wilderness: Struggles over livelihood and nature preservation in Africa; University of California Press: Los Angeles, CA, USA, 1998.

56. Murombedzi, J. Pre-colonial and colonial conservation practices in southern Africa and their legacy today; IUCN: Harare, Zimbabawe, 2003. Available online: http://dss.ucsd.edu/ $\sim$ ccgibson/docs/Murombedzi\%20\%20Precolonial\%20and\%20Colonial\%20Origins.pdf (Accessed 3 July 2009).

57. Prins, H.H.T., Grootenhuis, J.G., Dolan, T.T., Eds. Wildlife conservation by sustainable use; Kluwer Academic Publishers: Dordrecht, The Netherlands, 2000.

58. Bonner, R. At the hand of man. Peril and hope for Africa's wildlife; Alfred A., Ed.; Knopf: New York, NY, USA, 1993. 
59. Vanderpost, C. Protected areas in Ngamiland, Botswana: Investigating options for conservationdevelopment through human footprint mapping. Int. J. Environ. Stud. 2007, 64, 555-570.

60. Colchester, M. Salvaging nature: Indigenous peoples, protected areas and biodiversity conservation, 2nd ed; World Rainforest Movement, International Secretariat: Maldonado 1858, Montevideo; Forest Peoples Program: Moreton-in-Marsh, UK, 2003. Available online: http://www.wrm.org.uy/subjects/PA/texten.pdf (Accessed 8 July 2009).

61. Chape, S.; Blyth, S.; Fish, L.; Fox, P.; Spalding, M. United Nations list of protected areas; IUCN: Gland, Switzerland and Cambridge, UK; UNEP World Conservation Monitoring Centre, Cambridge, UK, 2003. Available online: http://www.unepwcmc.org/wdpa/unlist/ 2003_UN_LIST.pdf(Accessed 9 July 2009).

62. Dowie, M. Conservation refugees. Available online: http://www.orionmagazine.org/index.php/ articles/article/161/ (Accessed 10 July 2009).

63. Geisler, C.; de Sousa, R. From refugee to refugee: The African case. Working Paper 38; Land Tenure Centre, University of Wisconsin: Madison, WI, USA, 2000. Available online: http://ageconsearch.umn.edu/bitstream/12777/1/1tcwp38.pdf (Accessed 7 July 2009).

64. World database on protected areas as of January 31 2008; UNEP/WCMC: Cambridge, UK, 2009. Available online: http://www.wdpa.org/ (Accessed 15 March 2009).

65. Brockington, D.; Igoe, J. Anthropology conservation protected areas and identity politics. QEG conference paper; Oxford Department of International Development: Oxford, UK, 2005. Available online: http://www.qeh.ox.ac.uk/dissemination/conference-papers/brockington.pdf (Accessed 1 August 2009).

66. Brockington, D.; Igoe, J. Eviction for conservation. A global overview. Conservation and Society 2006, 4, 424-470. Available online: http://www.conservationrefugees.org/pdfdoc/ EvictionforConservation.pdf (Accessed 1 August 2009).

67. Brockington, D.; Igoe, J.; Schmidt-Soltau, K. Conservation, human rights, and poverty reduction. Conservation Biology 2006, 20, 250-252. Available online: http://www.colby.edu/environ/ courses/ES118/Readings/Brockington\%20et\%20al\%202006.pdf (Accessed 1 August 2009).

68. Igoe, J.; Croucher, B. Poverty reduction meets the spectacle of nature: does reality matter? Transnational influence in large landscape conservation in Northern Tanzania. Draft, 2006. Igoe, Assistant Professor, Department of Anthropology, University of Colorado at Denver, james.igoe@cudenver.edu; Croucher, student, Department of Anthropology, University of Colorado at Denver, becroucher@comcast.net.

69. Ogwang, D.A.; DeGeorges, A. Community participation in interactive park planning and the privatization process in Uganda's national parks; Prepared for Uganda National Parks (UNP): Kapala, Uganda; The U.S. Agency for International Development (USAID): Nairobi, Kenya, 1992.

70. Hulme, D. Community conservation in practice: A case study of Lake Mburo National Park. Working Paper No. 3. Community Conservation Research in Africa. Principles and Comparative Practice. Institute for Development Policy and Management, University of Manchester: Manchester, UK, 1997. Available online: http://www.sed.manchester.ac.uk/ idpm/research/publications/archive/cc/cc_wp03.pdf (Accessed August 2009). 
71. Magome, H.; Grossman, D.; Fakir, S.; Stowell, Y. Partnerships in conservation: The state, private sector and the community at Madikwe Game Reserve, North-West Province, South Africa. Evaluating Eden Series, Discussion Paper No 7; International Institute for Environment and Development (IIED): London, UK, 2000. Available online: http://www.iied.org/pubs/ pdfs/7802IIED.pdf (Accessed August 2009).

72. Hitchcock, R.K.; Biesle, M.; Lee. R. The San of Southern Africa: A status report. American Anthropological Association: Arlington, VA, USA, 2003. Available online: http://www.aaanet.org/committees/cfhr/san.htm. (Accessed 1 August 2009).

73. Survival International. The Bushmen; Survival International: London, UK, 2009. Available online: http://www.survival-international.org/tribes/bushmen/ (Accessed 1 August 2009).

74. Duffy, R. Killing for conservation. Wildlife policy in Zimbabwe. African Issues; The International African Institute in association with James Currey: Oxford, UK; Indiana University Press: Bloomington \& Indianapolis, USA; Weaver: Harare, Zimbabwe, 2000.

75. Child, G. Wildlife and people. The Zimbabwean success. How conflict between animals and people became progress for both; Wisdom Foundation: Harare, Zimbabwe; New York, NY, USA, 1995.

76. Hasler, R. An overview of the social, ecological and economic achievements and challenges of Zimbabwe's CAMPFIRE Project. Evaluating Eden Series, Discussion Paper No 3; International Institute for Environment and Development (IIED): London, UK, 1999. Available online: http://www.iied.org/pubs/pdfs/7796IIED.pdf (Accessed July 2009).

77. Bond, I. CAMPFIRE and the incentives for institutional change. In African wildlife and livelihoods: The promise and performance of community conservation; Hulme, D., Murphree, M., Eds.; James Curry: Oxford, UK, 2001.

78. Sibanda, B. Community wildlife management in Zimbabwe: The case of CAMPFIRE in the Zambezi Valley. In Rights, resource and rural development. Community-based natural resource management in Southern Africa; Fabricius, C., Kock, E., Magome, H., Turner, S., Eds.; Earthscan: London, UK, 2004; pp. 248-258.

79. Murphree, M.W. Congruent objectives, competing interests and strategic compromise: Concepts and processes in the evolution of Zimbabwe's CAMPFIRE program. Working Paper No. 2. Community Conservation Research in Africa. Principles and Comparative Practice; Institute for Development Policy and Management, University of Manchester: Manchester, UK, 1997. Available online: http://www.sed.manchester.ac.uk/idpm/research/publications/archive/ cc/cc_wp02.pdf. (Accessed 8 July 2009).

80. Living with wildlife. How CAMPFIRE communities conserve their natural resources; African Resources Trust: Harare, Zimbabwe, 2002.

81. Metcalfe, S. Whose resources are at stake? Community-based conservation and community self-governance. The Rural Extension Bulletin 1996, 10, 14-18.

82. Murombedzi, J.C. The dynamics of conflict in environmental management policy making in the context of the communal lands management program for indigenous resources (CAMPFIRE). Ph.D. Thesis; Centre for Applied Social Sciences, University of Zimbabwe: Harare, Zimbabwe, 1994. 
83. Murombedzi, J.C. Devolution and stewardship in Zimbabwe's CAMPFIRE program. J. Int. Devel. 1999, 11, 287-293.

84. ADMADE Foundation. Communities managing wildlife to raise rural standards of living and conserve biodiversity. Wildlife Conservation Society: New York, NY, USA; National Parks; Wildlife Service: Lusaka, Zambia, 1999.

85. DeGeorges, A. An evaluation. Today and the future. Policy issues and direction; USAID/Zambia and NPWS/Zambia: Lusaka, Zambia, 1992.

86. Lyons, A. An effective monitoring framework for Community-Based Natural Resource Management: A case study of the ADMADE program in Zambia. M.Sc. Thesis; University of Florida: Gainesville, USA, 2000. Available online: www.cbnrm.net/pdf/ lyons_a_001_admadethesis.pdf. (Accessed 9 July 2009).

87. Lewis, D.M.; Alpert, P. Trophy hunting and wildlife conservation in Zambia. Conserv. Biol. 1997, 11, 50-68.

88. Manning, I.P.A. A review of conservation and safari hunting on Zambia's customary land; 2006 (in press).

89. Marks, S.A. Large mammals and a brave people. Subsistence hunters in Zambia; University of Washington Press: Seattle, WA, USA, 1976.

90. Marks, S.A. Local hunters and wildlife surveys: a design to enhance participation. Afr. J. Ecol. 1994, 32, 233-254.

91. Marks, S.A. Local hunters and wildlife surveys: An assessment and comparison of counts for 1989, 1990 and 1993. Afr. J. Ecol. 1996, 34, 237-257.

92. Marks, S.A. Back to the future: Some unintended consequences of Zambia's community-based wildlife program (ADMADE). Afr. Today 2001, 48, 121-141.

93. Marks, S.A. The legacy of a Zambian community-based wildlife program. A cautionary tale. In Natural resources as community assets. Lessons from two continents; Lyman, M.W., Child, B., Eds.; Sand County Foundation: Madison, WI, USA; The Aspen Institute: Washington, DC, USA, 2005; pp. 183-209. Available online: http://www.sandcounty.net/assets/chapters/ forward_introduction.pdf. (Accessed 7 July 2009).

94. Marks, S.A.; Fuller, R.J. Enclosure of an important wildlife commons in Zambia; University of Gloucestershire: Cheltenham, UK, 2008. Available online: http://dlc.dlib.indiana.edu/archive/ 00003874/00/Marks_149401.pdf. (Accessed 7 July 2009).

95. Boggs, L.P. Community power, participation, conflict and development choice: Community wildlife conservation in the Okavango region of Northern Botswana. Evaluating Eden Series, Discussion Paper No 17; International Institute for Environment and Development (IIED): London, UK, 2000. Available online: http://www.iied.org/pubs/pdfs/7815IIED.pdf. (Assessed 8 July 2009).

96. Boggs, L. Community-based natural resource management in the Okavango Delta. In Rights, resource and rural development. Community-based natural resource management in Southern Africa; Fabricius, C., Kock, E., Magome, H., Turner, S., Eds.; Earthscan: London, UK, 2004; pp. 147-159.

97. Jones, B. Community-based natural resource management in Botswana and Namibia: An inventory and preliminary analysis of progress. September. Evaluating Eden Series, Discussion 
Paper No 6; International Institute for Environment and Development (IIED): London, UK, 1999. Available online: http://www.iied.org/pubs/pdfs/7799IIED.pdf. (Accessed 7 July 2009).

98. Berger, D.J. The making of a conservancy. The evolution of Nyae Nyae Conservancy. Restoring human dignity with wildlife wealth, 1997-2002; WWF/LIFE Program; USAID: Windhoek, Namibia, 2003.

99. Jones, B. Rights, revenue and resources: The problems and potential of conservancies as community wildlife management institutions in Namibia. Evaluating Eden Series, Discussion Paper No 2; International Institute for Environment and Development (IIED): London, UK, 1999. Available online: http://www.iied.org/pubs/pdfs/7795IIED.pdf. (Accessed 9 July 2009).

100. Livelihoods and CBNRM in Namibia: The findings of the WILD Project. Final Technical Report of the Wildlife Integration for Livelihood Diversification Project (WILD); Long, S.A., Ed.; Directorates of Environmental Affairs and Parks and Wildlife Management, Ministry of Environment and Tourism, the Government of the Republic of Namibia: Windhoek, Namibia, 2004. Available online: http://www.met.gov.na/programmes/wild/finalreport/TOC/ TOC(p1-4).pdf (Accessed 7 July 2009).

101. USAID Support to the community-based natural resource management program in Namibia: LIFE program review; United States Agency for International Development (USAID), Biodiversity Assessment and Technical Support (BATS) Program: Washington, DC, USA, 2008. Available online: http://pdf.usaid.gov/pdf_docs/PDACL549.pdf (Accessed 8 July 2009).

102. Weaver, L.C.; Skyer, P. Conservancies: integrating wildlife land-use options into the livelihood, development, and conservation strategies of Namibian communities. A Paper Presented at the 5th World Parks Congress to the: Animal Health and Development (AHEAD) Forum: Durban, South Africa, 2003. Available online http://www.usaid.gov/na/pdfdocs/WPCAHEAD_2.pdf (Accessed 8 July 2009).

103. Weaver, L.C.; Skyer, P. Conservancies: Integrating wildlife land-use options into the livelihood, development and conservation strategies of Namibian communities. In Conservation and development interventions at the wildlife/livestock interface. Implications for wildlife, livestock and human health; Osofsky, S.A., Ed.; Occasional Paper of the IUCN Species Survival Commission No. 30; IUCN: Gland, Switzerland; Cambridge, UK, 2005; pp. 89-104. Available online: http://iucn.org/dbtw-wpd/edocs/SSC-OP-0301r.pdf (Accessed 7 July 2009).

104. Wiessner, P. Population, subsistence, and social relations in the Nyae Nyae Area: Three decades of change; Report on file at the Nyae Nyae Development Foundation of Namibia: Windhoek, Namibia, 1999.

105. Ashley, C.; Mdoe, N.; Reynolds, L. Rethinking wildlife for livelihoods and diversification in rural Tanzania: A case study from Northern Selous. LADDER Working Paper No.15; DFID: London, UK, 2002. Available online: http://www.odi.org.uk/resources/download/2927.pdf (Accessed 6 July 2009).

106. Baldus, R.D.; Hahn, R.; Kaggi, D.; Kaihula, S.; Murphree, M.; Mahundi, C.C.; Roettcher, K.; Siege, L.; Zacharia, M. Experiences with community based wildlife conservation in Tanzania. Tanzania Wildlife. Discussion Paper No 29; Wildlife Division/GTZ: Dar es Salaam, Tanzania, 2001. Available online: http://www.wildlife-programme.gtz.de/wildlife/download/nr_29_1.pdf (Accessed 7 July 2009). 
107. Baldus, R.D.; Kaggi, D.T.; Ngoti, P.M. Community based conservation (CBC): Where are we now? Where are we going? 15 years of CBC. In The Newsletter of the Wildlife Conservation Society of Tanzania, Miombo, 2004. Available online: http://www.wildlife-programme.gtz.de/ wildlife/download/cbc.pdf (Accessed 9 July 2009).

108. Barrow, E.; Gichohi, H.; Infield, M. Rhetoric or reality? A review of community conservation and practice in East Africa. Evaluating Eden Series No 5; International Institute for Environment and Development (IIED): London, UK, 2000. Available online: http://www.iied.org/pubs/pdfs/7807IIED.pdf (Accessed 7 July 2009).

109. Clarke, J.E. An evaluation of the Cullman and Hurt Community Wildlife Project, Tanzania. Conservation Force 2001.

110. Gillingham, S. Giving wildlife value: A case study of community wildlife management around the Selous Game Reserve, Tanzania; Department Biological Anthropology, University of Cambridge: Cambridge, UK, 1998.

111. Junge, H. Decentralisation and community-based natural resource management in Tanzania. The case of local governance and community-based conservation in districts around the Selous Game Reserve. Tanzania Wildlife Discussion Paper No. 32; Wildlife Division Deutsche Gesellschaft für Technische Zusammenarbeit GTZ Wildlife Program: Dar Es Salaam, Tanzania, 2002. Available online: http://www.wildlife-baldus.com/download/nr_32.pdf (Accessed 9 July 2009).

112. Kibonde, B.O. Wildlife poaching in Tanzania: Case study of the Selous Game Reserve; Tshwane University of Technology: Pretoria, South Africa, 2005.

113. Child, B. The Luangwa Integrated Development Project, Zambia. In Rights, resource and rural development. Community-based natural resource management in Southern Africa; Fabricius, C., Kock, E., Magome, H., Turner, S., Eds.; Earthscan: London, UK, 2004; pp. 235-247.

114. Child, B.; Clayton, B.D. Transforming approaches to CBRNM: Learning from the Luangwa experience; Southern Africa Sustainable Use Specialist Group, IUCN-The World Conservation Union Regional Office for Southern Africa: Harare, Zimbabwe, 2002. Available online: http://www.sasusg.net/web/files/papers/CBNRM\%20in\%20Lupande\%20GMA\%20\%20Brian\%2 0Child\%20and\%20Dalal\%20Clayton\%20.pdf (Accessed 9 July 2009).

115. Murphree, M.W. Community based conservation: Old ways, new myths and enduring challenges. In Experiences with community based wildlife conservation in Tanzania; Baldus, R.D., Hahn, R., Kaggi, D., Kaihula, S., Murphree, M., Mahundi, C.C., Roettcher, K., Siege, L., Zacharia, M., Eds.; Tanzania Wildlife Discussion Paper No 29; Wildlife Division/GTZ: Dar es Salaam, Tanzania, 2001. Available online: http://www.wildlife-programme.gtz.de/wildlife/ download/nr_29_1.pdf. (Accessed July 2009).

116. Barrow, E.; Murphree, M. Community conservation from concept to practice: A practical framework. Working Paper No. 8; Institute for Development Policy and Management, University of Manchester: Manchester, UK, 1998. Available online: http://www.sed.manchester.ac.uk/idpm/research/publications/archive/cc/cc_wp08.pdf (Accessed 7 July 2009).

117. Jones, T.B.B.; Murphree, M.W. Community-based natural resources management as a conservation mechanism: Lessons and directions. In Parks in transition. Biodiversity, rural 
development and the bottom line; Child, B., Ed.; Earthscan Publications: London, UK, 2004; pp. 63-103.

118. Murombedzi, J. Devolving the expropriation of nature. The 'devolution' of wildlife management in southern Africa. In Decolonizing nature. Strategies for conservation in a post-colonial era; Adams, W., Mulligan, M., Eds.; Earthscan Publications: London, UK, 2003; pp. 135-151.

119. Rights, resource and rural development. Community-based natural resource management in Southern Africa; Fabricius, C., Kock, E., Magome, H., Turner, S., Eds.; Earthscan: London, UK; Sterling, Virginia, 2004.

120. IUCN/SASUSG. Community wildlife management in Southern Africa a regional review. November. IUCN-The World Conservation Union Regional Office For Southern Africa, Southern Africa Sustainable Use Specialist Group (SASUSG). Evaluating Eden Series, Working Paper No. 11; International Institute for Environment and Development (IIED): London, UK, 1997. Available online: http://www.iied.org/pubs/pdfs/7805IIED.pdf (Accessed 9 July 2009).

121. Hurt, R.; Ravn, P. Hunting and benefits: An overview of hunting in Africa with special reference to Tanzania. In Wildlife conservation by sustainable use; Prins, H.H.T., Grootenhuis, J.G., Dolan, T.T., Eds.; Lower Academic Publishers: Boston, Mass, USA, 2000; pp. 295-314.

122. de la Harpe, D.; Fernhead, P.; Hughes, G.; Davies, R.; Spenceley, A.; Barnes, J.; Cooper, J.; Child, B. Does commercialization of protected areas threaten their conservation goals? In Parks in transition. Biodiversity, rural development and the bottom line; Child, B., Ed.; Earthscan Publications: London, UK, 2004; pp. 189-216.

123. Patel, H. Sustainable utilization and African wildlife policy: The case of Zimbabwe's Communal Areas' Management Program for Indigenous Resources (CAMPFIRE): Rhetoric of reality; Indigenous Environment Policy Centre: Cambridge, USA, 1998. In An overview of the social, ecological and economic achievements and challenges of Zimbabwe's CAMPFIRE Project; Hasler, R., Ed.; Evaluating Eden Series, Discussion Paper No 3; International Institute for Environment and Development (IIED): London, UK, 1999. Available online: http://www.iied.org/pubs/pdfs/7796IIED.pdf. (Accessed 7 July 2009).

124. RSA Community Organizations. Statement on hunting; Submitted to the Panel of Experts on Professional and Recreational Hunting, Ministry of Environment and Tourism: Pretoria, South Africa, 2005. Available online: http://www.deat.gov.za/HotIssues/2005/29062005/ Community_statement_on_Hunting.doc (Accessed July 2009).

125. Junge, H. Democratic decentralization of natural resources in Tanzania. The case of local governance and community-based conservation in districts around the Selous Game Reserve; GTZ. Tropical Ecology Support Program (TOEB): Eschborn, Germany, 2004.

126. Rigava, N.; Chinhoyi, C. Community-based natural resource management. A case for the CAMPFIRE program in Zimbabwe". A Figure/Poster. Provided by Norman Rigava then with WWF/Zimbabwe, 1997.

127. Murphree, M.W. Synergizing conservation incentives: from local-global conflict to compatibility. Working Paper No. 7. Community Conservation Research in Africa. Principles and Comparative Practice; Institute for Development Policy and Management, University of Manchester: Manchester, UK, 1998. Available online: http://www.sed.manchester.ac.uk/ $\mathrm{idpm} /$ research/publications/archive/cc/cc_wp07.pdf (Accessed 8 July 2009). 
128. Emerton, L. The nature of benefits and the benefits of nature: Why wildlife conservation has not economically benefited communities in Africa. Working Paper No. 5. Community Conservation Research in Africa. Principles and Comparative Practice; Institute for Development Policy and Management, University of Manchester: Manchester, UK, 1998. Available online: http://www.sed.manchester.ac.uk/idpm/research/publications/archive/cc/cc_wp05.pdf (Accessed 9 July 2009).

129. Waithaka, J. Maasai Mara - an ecosystem under siege: an African case study on the social dimension of rangeland conservation. Afr. J. Range For. Sci. 2004, 21, 79-88.

130. Katerere, Y.; Chikoku, H. Can devolution deliver benefits of community-based natural resource management (CBNRM) initiatives? IUCN Regional Office Southern Africa (ROSA): Harare, Zimbabwe. In WSP. The long walk to sustainability. A Southern African perspective. World Summit Publication, HIS: Johannesburg, South Africa, 2002; pp. 53-55.

131. Baldus, R.D.; Cauldwell, A.E. Tourist hunting and its role in development of Wildlife Management Areas in Tanzania. GTZ: Dar es Salaam, Tanzania, 2004. Available online: http://www.cic-wildlife.org/uploads/media/Hunting_Tourism.pdf (Accessed 1 August 2009).

132. Watkin, J.R. The evolution of ecotourism in East Africa: From an idea to an industry. Summary of the Proceedings of the East African Regional Conference on Ecotourism, 19-23 March, 2002. Wildlife and Development Series No. 15; International Institute for Environment and Development (IIED): London, UK, 2003. Available online: http://www.iied.org/pubs/pdfs/ 9223IIED.pdf (Accessed 1 August 2009).

133. Roe, D.; Mayers, J.; Grieg-Gran, M.; Kothari, A.; Fabricius, C.; Hughes, R. Evaluating Eden: Exploring the myths and realities of community-based wildlife management. September. Evaluating Eden, Series No 8; International Institute for Environment and Development (IIED): London, UK, 2000. Available online: http://www.iied.org/pubs/pdfs/7810IIED.pdf (Accessed 9 July 2009).

134. Fairhead, J.; Leach, M. Science, society and power. Environmental knowledge and policy in West Africa and the Caribbean; Cambridge University Press: Cambridge, UK, 2003.

135. Roe, D.; Jack, M. Case studies of community-based wildlife Management. Evaluating Eden Series No 9; International Institute for Environment and Development (IIED): London, 2001. Available online: http://www.iied.org/pubs/pdfs/9012IIED.pdf (Accessed 6 August 2009).

136. WWF. Quota setting manual. Wildlife management series. WWF-World Wide Fund for Nature (formerly World Wildlife Fund) Program Office; Zimbabwe, Zimbabwe Trust: Harare, Zimbabwe; Safari Club International, Arizona, USA, 1997. Available online: http://www.wag-malawi.org/Quota\%20Setting\%20Manual.pdf (Accessed 1 August 2009).

137. WWF. Counting wildlife manual. WWF-World Wide Fund for Nature (formerly World Wildlife Fund) Southern African Regional Program Office (SARPO); Zimbabwe Trust: Harare, Zimbabwe; Safari Club International, Arizona, USA, 2000. Available online: http://www.wag-malawi.org/Counting\%20Wildlife.pdf. (Accessed 1 August 2009).

138. Hulme, D.; Taylor, R. Integrating environmental, economic and social appraisal in the real world: from impact assessment to adaptive management. In Sustainable development and integrated appraisal in a developing world; Lee, N., Kirkpatrick, C., Eds.; Edward Elgar: Cheltenham, UK, 2000. 
139. Parker, I. What I tell you three times is true. Conservation, ivory, history and politics. Librario Publishing: Moray, UK, 2004.

140. DeGeorges, A. "Field notes Tanzania, September 11-22”. SCI African Office Manager: Pretoria, South Africa, 1999 (Unpublished).

141. Hutton, J.; Adams, W.M.; Murombedzi, J.C. Back to the barriers? Changing narratives in biodiversity conservation. Forum for Development Studies 2005, 32. Available online: http://rmportal.net/library/files/back-to-barriers.pdf/view?set_language=es (Accessed 1 August 2009).

142. Jones, J. Transboundary conservation in Southern Africa: Exploring conflict between local resource access and conservation; Centre for Environmental Studies: University of Pretoria South Africa, 2003. Available online: http://www.iapad.org/publications/ppgis/jones.jennifer.pdf (Accessed 1 August 2009).

143. Decolonizing nature. Strategies for conservation in a post-colonial era; Adams, W., Mulligan, M., Eds.; Earthscan Publications: London, UK, 2003.

144. Dzingirai, V. Disenfranchisement at large transfrontier zones, conservation and local livelihoods; IUCN ROSA: Harare, Zimbabwe, 2004.

145. Nelson, J. Still off of the conservation map in Central Africa: Bureaucratic neglect of forest communities in Cameroon. World Rainforest Movement: Montevideo, Uruguay, 2003. Available online: http://www.wrm.org.uy/countries/Cameroon/still.html (Accessed 1 August 2009).

146. Peterson, D. Eating apes; University of California Press: Berkeley, CA, USA, 2003.

147. Hagberg, S. The authority and violence of a hunters' association in Burkina Faso. "Each bird is sitting in its own tree. In Conflicts over land and water in Africa; Derman, B., Odgaard, R., Sjaastad, E., Eds.; James Curry: Oxford, UK; Michigan State University Press, East Lansing, MI, USA; University of KwaZulu-Natal Press, Pietermaritzburg: South Africa, 2007; pp. 187-201.

148. Thomson, R. A game warden's report. The state of wildlife in Africa at the start of the third millennium; Magron Publishers: Hartbeespoort, South Africa, 2003.

149. Norton-Griffiths, M. How many wildebeest do you need? World Economics 2007, 8, 41-64. Available online: http://mng5.com/papers/HowMany.pdf (Accessed 8 July 2009).

150. Maliti, H.T. The use of GIS as a tool in wildlife monitoring in Tanzania: A case study on the impact of human activity on wildlife in the Tarangire-Manyara ecosystem. Nature Conservation in the Department of Nature Conservation Faculty of Agricultural Sciences, Tshwane University of Technology: Pretoria, South Africa, 2007.

151. Cumming, D. Elephantine dilemmas. Academy of Science South Africa. Quest 2005, 1, 14-17.

152. Magome, H.; Fabricius, C. Reconciling biodiversity conservation with rural development: The holy grail of CBNRM. In Rights, resource and rural development. Community-based natural resource management in Southern Africa; Fabricius, C., Kock, E., Magome, H., Turner, S., Eds.; Earthscan: London, UK, 2004; pp. 93-111.

153. Hara, M. Beach village committees as a vehicle for community participation: Lake Malombe/Upper Shire River participatory program. In Rights, resource and rural development. Community-based natural resource management in Southern Africa; Fabricius, C., Kock, E., Magome, H., Turner, S., Eds.; Earthscan: London, UK, 2004; pp. 182-193. 
154. Sasa, M. The Persian Gulf of strategic minerals of our earth. New African 2007. Available online: http://findarticles.com/p/articles/mi_qa5391/is_200708/ai_n21294087/ (Accessed 1 August 2009).

155. DeGeorges, A. Conservation and development. History and direction in Africa preparing for the 21st century. Prepared as final briefing document as Regional Environmental Advisor East and Southern Africa for USAID/REDSO/ESA: Nairobi, Kenya, 1992.

156. Schaller, G. The mountain gorilla. Ecology and behaviour; University of Chicago Press, Midway Reprint: Chicago, IL, USA; London, UK, 1976.

157. Wild, R.G.; Mutebi, J. Conservation through community use of plant resources. Establishing collaborative management at Bwindi Impenetrable and Mgahinga Gorilla National Parks, Uganda. People and Plants. Working Paper No. 5; UNESCO: Paris, France, 2005. http://www.peopleandplants.org/storage/working-papers/wp5e.pdf (Accessed 1 August 2009).

158. Adams, W.M.; Infield, M. Community conservation at Mgahinga Gorilla National Park, Uganda. Working Paper No. 10. Community Conservation Research in Africa. Principles and Comparative Practice; Institute for Development Policy and Management, University of Manchester: Manchester, UK, 1998. Available online: http://www.conservationfinance.com/ Documents/GEF\%20FA\%20papers/adams_and_infield.pdf. (Accessed 1 August 2009).

\section{Notes}

i. The maji or magic water reputed to prevent German bullets from killing, came from a shallow well called Kisima Mkwanga by Kingupira in the eastern Selous. The Germans applied a scorched earth policy_burning huts, laying waste and destroying crops. The Maji Maji fighters did the same against villages which did not join them [40].

ii. Tsetse fly is the vector of human and bovine sleeping sickness/trypanosomiasis. Although there are trypanotolerant cattle such as the N'Dama in West Africa and the Nguni in Southern Africa, over much of Africa tsetse fly areas are dominated by wildlife over livestock.

iii. Traditional Arab sailing vessel common off the East Africa coast.

iv. Use of the name "World Conservation Union", in conjunction with IUCN, began in 1990. From March 2008 this name is no longer commonly used. Available online: http://www.iucn.org/about/ (Accessed July 2009).

v. A term coined by well known and widely travelled Zimbabwean professional hunter, Andy Wilkinson, who has seen this phenomenon occurring all over the wilds of rural Africa.

vi. "Open Access Resources" are those owned by the state, belonging to everyone but the responsibility of no one but the state that resulted from the imposition of centralized management systems with the coming of colonialism. For the most part this carried on after independence. The state tended/s to be incapable of controlling access by its alienated people. Africans began mining wildlife as a short-term resource in favour of long-term investments in other economic sectors over which they had control, such as farming and livestock. This is as opposed to traditional "Common Property Resources", belonging to and managed by the community as opposed to the individual or state. 
vii. Washington Consensus policies of the International Monetary Fund (IMF) and the World Bank that markets by themselves will lead to efficient outcomes driven by a profit motive, based on free-market fundamentalism laissez-faire policies. This included conditionalities imposed on developing countries to obtain loans, such as cutbacks in government expenditures, especially in social spending (e.g., education and health); rollback or containment of wages, privatization of state enterprises and deregulation of the economy, elimination or reduction of protection for the domestic market and less restrictions on the operations of foreign investors, successive devaluations of the local currency in the name of achieving export competitiveness, increased interest rates, and elimination of food and agricultural subsidies. The underlying intention was to minimize the role of the state. The folly of SAPs was brought out in the April 2009 G20 and the Summit of the Americas meetings, forcing the IMF to state that it will change how it relates to the developing world.

viii. Note: Gross indicates total benefits divided among households. Often benefits never reach household, used for common property benefits and/or to run community organization (e.g., conservancy, trust, Section 21 company, association, etc.). Nett is what is left over for payment to the community for both household and/or common property benefits.

ix. (Net Profit To Company/Gross Profit) $\times 100$

x. Columbite-Tantalite.

xi. Income in local currency is converted to U.S. dollars, and official exchange rate adjusted for cost-of-living differences between the U.S. and country in question, allowing comparison of incomes across countries.

(C) 2009 by the authors; licensee Molecular Diversity Preservation International, Basel, Switzerland. This article is an open-access article distributed under the terms and conditions of the Creative Commons Attribution license (http://creativecommons.org/licenses/by/3.0/. 